\title{
Concrete Reflected Arrays of U(93.2) Metal
}

Mackenzie Gorham John D. Bess J. Blair Briggs Virginia Dean Davis Reed

September 2010

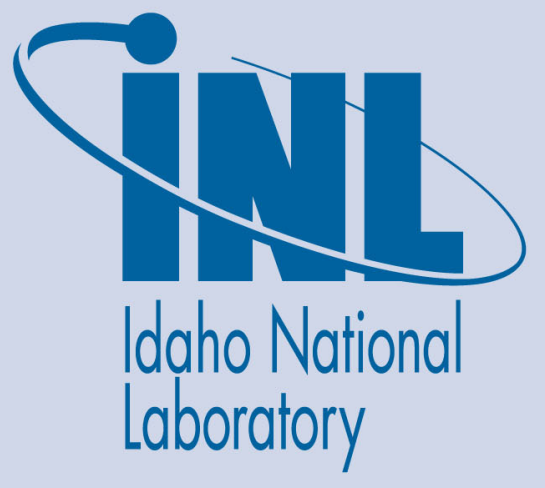

The INL is a U.S. Department of Energy National Laboratory operated by Battelle Energy Alliance 
INL/EXT-10-17643

\title{
Concrete Reflected Arrays of U(93.2) Metal
}

\author{
Mackenzie Gorham ${ }^{1}$ \\ John D. Bess \\ J. Blair Briggs \\ Virginia Dean ${ }^{2}$ \\ Davis Reed ${ }^{3}$
}

${ }^{1}$ Idaho State University/ldaho National Laboratory

${ }^{2}$ Under Subcontract to the Idaho National Laboratory

30ak Ridge National Laboratory

September 2010

Idaho National Laboratory

Idaho Falls, Idaho 83415

http://www.inl.gov

Prepared for the

U.S. Department of Energy

Office of Nuclear Energy

Under DOE Idaho Operations Office

Contract DE-AC07-05ID14517 


\title{
CONCRETE REFLECTED ARRAYS OF U(93.2) METAL
}

\author{
Evaluator \\ Mackenzie Gorham \\ Idaho State University \\ Idaho National Laboratory \\ Internal Reviewers \\ John D. Bess \\ J. Blair Briggs \\ Independent Reviewers \\ Virginia Dean \\ Under Subcontract to the Idaho National Laboratory \\ Davis Reed \\ Oak Ridge National Laboratory
}


NEA/NSC/DOC/(95)03/II

Volume II

HEU-MET-FAST-054

\section{ACKNOWLEDGEMENTS}

The author would like to acknowledge Virginia Dean, subcontractor to the Idaho National Laboratory, for help in expanding discussions and adding details to some descriptions in the report and Christine White, Idaho National Laboratory, for rendering images of the experimental configurations and figures used for model description. 
NEA/NSC/DOC/(95)03/II

Volume II

HEU-MET-FAST-054

\section{CONCRETE REFLECTED ARRAYS OF U(93.2) METAL}

\section{IDENTIFICATION NUMBER: HEU-MET-FAST-054}

KEY WORDS: critical experiment, concrete reflected, cylinders, highly enriched uranium, Magnuson concrete, three-dimensional arrays, unacceptable

\subsection{DETAILED DESCRIPTION}

\subsection{Overview of Experiment}

During the period from 1963 - 1973, experiments involving highly enriched uranium units were performed at the Oak Ridge National Laboratory Critical Experiments Facility to determine various critical configurations of three-dimensional arrays. The experiments formed a four-part series and were reported by several different experimenters; the results of interest for this evaluation are those reported for the fourth experimentation, Critical Three-Dimensional Arrays of Neutron Interacting Units: Part IV, published and performed by D.W. Magnuson (Ref 1). Information is also available in the experimental logbook. ${ }^{a}$ This set of experiments, performed November 13- 17 of 1972, utilized subcritical metal units on a split table apparatus to determine critical configurations for $2 \times 2 \times 2$ arrangements of highly enriched uranium reflected by concrete.

Magnuson manipulated the configuration of several uranium cylinders and blocks within a concrete reflector. The different permutations utilized uranium cylinders of two different heights in various positions in the three dimensional array; certain cases also placed thin uranium blocks on top of the cylinders. The thickness of the surrounding concrete, as well as the inner dimensions of the concrete reflector, was also varied in certain cases. The variations resulted in fourteen different experimental permutations or configurations. All fourteen configurations were judged to be unacceptable for use as criticality benchmark experiments due to apparent large extrapolations to obtain experimental $\mathrm{k}_{\text {eff }}$ values with no supporting data and large uncertainties in the concrete composition and density data.

All experiments were initially evaluated; however only three configurations were evaluated in detail. Configurations 2, 4, 6 and 12 were not evaluated in detail because they are subcritical and Configurations $5,7,8,9$, and 10 were also were not evaluated in detail because they were extrapolated or corrected to values greater than beta effective $(\sim 0.007)$ above delayed critical, or prompt critical. The experiments evaluated in detail for this report were Configurations 1,3 , and 11.

The experimental report also contains information for HEU-MET-FAST-056. Closely related work has been recorded in HEU-MET-FAST-053, which is an evaluation of a different series of three dimensional array experiments with four different moderator materials. HEU-MET-FAST-023 and HEU-MET-FAST-026 are also related because they utilize the same metal cylinders as these experiments (Ref. 1).

a Oak Ridge Critical Experiments Logbook 27R: “Auto Radiography/Arrays 8-unit/U-cylinders/UO2, 1970, D.W. Magnuson”, RSICC/Oak Ridge National Laboratory, 1999, pages 102-140. http://www-rsicc.ornl.gov/CriticalExperiments/book27r.pdf. Accessed Summer 2010. 
NEA/NSC/DOC/(95)03/II

Volume II

HEU-MET-FAST-054

\subsection{Description of Experimental Configuration}

1.2.1 Uranium Pieces - The main critical material in this series of experiments consisted of eight 10.8 $\mathrm{cm}$ tall highly enriched uranium (HEU) metal cylinder pairs with an outside diameter of $11.52 \mathrm{~cm}$ and a reported average mass of $20.962 \mathrm{~kg}$ (misstated as $20.962 \mathrm{~g}$ in Ref.1). The cylinders were constructed of two units each, and the two units were stacked together to form a cylinder of the given dimensions; for this reason, these units are sometimes referred to as cylinder pairs. The dimensional measurements have a reported deviation $\pm 0.003 \mathrm{~cm}$ (Ref. 2). The given mass was averaged from the individual measured weights of each unit, and confirmed by measuring the mass of an assembled cylinder pair. These mass measurements were reported to vary by as much as 3\% (Ref. 2). The cylinders also have two small holes drilled through them, which allowed for vertical placement on steel rods when these uranium cylinders were used in the Tinkertoy experiments (HEU-MET-FAST-023 and HEU-MET-FAST-026). These holes run lengthwise through the cylinders with a radius of $0.508 \mathrm{~cm}$, and they are spaced $8.547 \mathrm{~cm}$ apart (Ref. 2). Support rods running through the uranium were not used in this set of experiments. The measured mass of each cylinder pair, as well as the reported table placement is described in Table 1. Note that the south half of the table was fixed, and the north half was movable.

Table 1. Measured Mass of Large Uranium Cylinders (Ref. 1). ${ }^{(a)}$

\begin{tabular}{||c|c|c|c||}
\hline \hline Unit & Cylinder Pair & $\begin{array}{c}\text { Table } \\
\text { Placement }\end{array}$ & Mass (kg) \\
\hline \hline 1 & 2176 and 2189 & SOUTH & 20.966 \\
\hline 2 & 2204 and 2205 & SOUTH & 20.966 \\
\hline 3 & 2168 and 2193 & SOUTH & 20.963 \\
\hline 4 & 2195 and 2196 & SOUTH & 20.962 \\
\hline 5 & 2170 and 2152 & NORTH & 20.960 \\
\hline 6 & 2156 and 2200 & NORTH & 20.959 \\
\hline 7 & 2162 and 2190 & NORTH & 20.962 \\
\hline 8 & 2172 and 2197 & NORTH & 20.961 \\
\hline
\end{tabular}

(a) ORNL Logbook 27R, pages 43, 107.

In addition to the main cylinder pairs, other uranium pieces added to the array's upper cells were used to achieve criticality variations. Smaller uranium cylinders of the same diameter as the above cylinder pairs, but weighing $5.2 \mathrm{~kg}$ and having a height of $2.7 \mathrm{~cm}$, were placed on top of the larger cylinders in certain permutations (Ref. 1). Also, thin uranium blocks were placed on the main cylinders to produce reactivity changes. These blocks were 5 in. $(12.7 \mathrm{~cm})$ square plates with thicknesses of $1 / 16$ in. $(0.15875 \mathrm{~cm}), 1 / 8$ in. $(0.3175 \mathrm{~cm})$, or $1 / 4$ in. $\left(0.6350 \mathrm{~cm}^{\mathrm{a}}\right)$. Table 2 lists the dimensions of the various uranium pieces. Dimensions were rounded to two decimal places in the experimental report, but the logbook provided more complete values.

\footnotetext{
a These values in inches are given in the text in Ref. 1 (p. 7). However, the dimensions given in the table in Ref. 1, which describes the details of the geometry of the configurations, indicates the thicknesses in $\mathrm{cm}$ of the layers of added thin blocks to only two decimal places, namely $0.16 \mathrm{~cm}, 0.32 \mathrm{~cm}, 0.48 \mathrm{~cm}$, and $0.64 \mathrm{~cm}$.
} 
NEA/NSC/DOC/(95)03/II

Volume II

HEU-MET-FAST-054

Table 2. Physical Description of Experimental Uranium Pieces (Ref. 1).

\begin{tabular}{|c|c|c|c|c||}
\hline Uranium Piece & Radius (cm) & Height (cm) & Width (cm) & Weight (kg) \\
\hline \hline Large Cylinder & 5.76 & 10.8 & na & 20.962 (avg) \\
\hline Small Cylinder & 5.76 & 2.7 & na & 5.2 \\
\hline Rectangular Plates & na & $\begin{array}{c}0.15875,0.3175, \\
\text { or } 0.6350\end{array}$ & 12.7 & Not reported \\
\hline
\end{tabular}

1.2.2 Aluminum Supports - Sheet aluminum 0.032 in $(0.08 \mathrm{~cm})$ thick ${ }^{\mathrm{a}}$ was used to provide a flat surface to place the uranium cylinders on. The sheets, or shelves, have "an area of two cells, and were placed at three levels within both halves of the critical assembly. When the assembly was closed, there was a shelf on the bottom reflector which spanned its whole area, as well as two more shelves suspended within the reflector, each shelf under the large uranium cylinder cells (Ref. 1, p. 74). The shelves were supported by $3 \times 3$ in. $(7.62 \times 7.62 \mathrm{~cm})$ square aluminum tubing that allowed for consistent alignment and placement of the uranium units within the reflector. The pieces of tubing formed small, hollow boxes that offered stability to the layers of uranium cylinders.

The experimental report suggested that the aluminum support parts had a reactivity worth of $0.0014 \Delta \mathrm{k} / \mathrm{k}$. All experimental $\mathrm{k}_{\mathrm{eff}}$ data for these experiments were reduced by this amount when reported in the experimental report (Ref. 1, p. 6, footnote d).

1.2.3 Steel Angle Support - A single piece of steel angle 40 inches $(101.6 \mathrm{~cm})$ long $^{\mathrm{b}}$ was stretched horizontally across the plane of separation on each half of the concrete reflector (Ref. 1). The steel angle served to ensure each half of the experimental array was steady and free-standing, a requirement when using a split table apparatus. The dimensions of the angled steel were $0.635^{\mathrm{c}} \times 5.08 \times 5.08 \mathrm{~cm}$. It was positioned in such a manner as to support the upper reflector, even as certain outer blocks were rearranged to achieve desired reactivity changes.

1.2.4 Concrete Shielding Blocks - The reflector was constructed from concrete blocks with nominal dimensions of $8 \times 16 \times 4$ in. $(20.32 \times 40.64 \times 10.16 \mathrm{~cm}) .{ }^{d}$ The average measurements taken of the stacked blocks were $20.50 \times 40.64 \times 10.22 \mathrm{~cm}$, and multiples of these average dimensions were used in the description of the experimental configurations. ${ }^{\mathrm{e}}$ The exact placement of the blocks was not specified in detail. Ref. 1, p. 9, says "because of roughness and irregularities in the concrete, the location of the concrete surface is known only to $\pm 0.2 \mathrm{~cm}$."

The concrete reflector dimensions were modified to achieve several permutations through the experiment. The various dimensions used for each experimental case are presented in Table 3. Reflectors on all sides were approximately $16 \mathrm{in}$. $(40.64 \mathrm{~cm})$ thick except in certain permutations where the reflector was 12 (30.48) or 8 in $(20.32 \mathrm{~cm})$ thick. Information depicted in images in the logbook on p134-135 indicates that some of the concrete reflector on the top and bottom layers hung over the sides of the other blocks, creating a lip above and below the main core that contained the uranium units. This lip was not dimensioned.

a Ref. 1 gives the value 0.032 without specifying units; however, a logbook diagram of the setup (logbook, page 106) shows the thickness as " $1 / 32 " \sim 0.08 \mathrm{~cm}$ ". (Note that $1 / 32=0.03125$, which is approximately 0.032 .)

${ }^{\mathrm{b}}$ Logbook 27R, page 106.

c Ref. 1 says the steel angle is $1 / 4$ " thick, but the logbook page 112 says $3 / 16 "(.47625 \mathrm{~cm})$ thick.

${ }^{d}$ Ref. 1, p. 7 and logbook, page 123.

e Ref 1, p7, footnote 10.

Revision: 0

Date: September 30, 2010

Page 3 of 36 
NEA/NSC/DOC/(95)03/II

Volume II

HEU-MET-FAST-054

Table 3. Concrete Reflector Dimensions (cm) of Closed Experimental Configurations (Ref. 1).

\begin{tabular}{|c|c|c|c|c|c|c|}
\hline $\begin{array}{c}\text { Configuration } \\
\text { Number }\end{array}$ & $\begin{array}{c}\text { Inner X } \\
\text { Dimension }\end{array}$ & $\begin{array}{c}\text { Inner Y } \\
\text { Dimension }\end{array}$ & $\begin{array}{c}\text { Inner Z } \\
\text { Dimension }\end{array}$ & $\begin{array}{c}\text { Outer X } \\
\text { Dimension }\end{array}$ & $\begin{array}{c}\text { Outer Y } \\
\text { Dimension }\end{array}$ & $\begin{array}{c}\text { Outer Z } \\
\text { Dimension }\end{array}$ \\
\hline \hline 1 & 60.96 & 61.44 & 61.92 & 142.24 & 143.44 & 143.68 \\
\hline 2 & 60.96 & 61.44 & 61.92 & 142.24 & 143.44 & 143.68 \\
\hline 3 & 55.88 & 61.44 & 61.92 & 137.16 & 143.44 & 143.68 \\
\hline 4 & 55.88 & 61.44 & 61.92 & 137.16 & 143.44 & 143.68 \\
\hline 5 & 48.26 & 61.44 & 61.92 & 129.54 & 143.44 & 143.68 \\
\hline 6 & 48.26 & 61.44 & 61.92 & 129.54 & 143.44 & 143.68 \\
\hline 7 & 45.72 & 61.44 & 61.92 & 127.00 & 143.44 & 143.68 \\
\hline 8 & 45.72 & 61.44 & 61.92 & 127.00 & 143.44 & 143.68 \\
\hline 9 & 45.72 & 61.44 & 61.92 & 127.00 & 143.44 & 143.68 \\
\hline 10 & 45.72 & 61.44 & 61.92 & 127.00 & 143.44 & 143.68 \\
\hline 11 & 45.72 & 61.44 & 61.92 & 127.00 & 143.44 & 143.68 \\
\hline 12 & 45.72 & 61.44 & 61.92 & $106.68^{(\mathrm{a})}$ & 143.44 & 143.68 \\
\hline 13 & 45.72 & 61.44 & 61.92 & 127.00 & $102.44^{(\mathrm{b})}$ & $123.24^{(\mathrm{c})}$ \\
\hline 14 & 45.72 & 61.44 & 61.92 & 127.00 & $102.44^{(\mathrm{b})}$ & $123.24^{(\mathrm{c})}$ \\
\hline
\end{tabular}

(a) In this case, one $\mathrm{X}$ reflector is $20.32 \mathrm{~cm}$ thick and the other is $40.64 \mathrm{~cm}$ thick.

(b) Both Y reflectors are $20.5 \mathrm{~cm}$ thick.

(c) The void is not centered vertically inside this reflector: the top reflector is $20.44 \mathrm{~cm}$ thick and the bottom reflector is $40.88 \mathrm{~cm}$ thick.

The top and bottom reflectors were made with two contiguous stacks of 40.64-cm-long blocks on each table half. The outer $\mathrm{X}$ dimensions varied because the $\mathrm{X}$ dimension of the core (which was between the top and bottom reflectors) changed as the cell's X dimensions varied between the 3 widths: 12 in., 10 in, and 9 in. (see Table 4).

1.2.5 Description of Experiment - The geometric configuration of the experiment can most simply be described as a cubical arrangement of concrete blocks surrounding uranium cylinders on thin aluminum shelves supported by hollow aluminum boxes. The shelves were positioned such that the aluminum boxes held them at a consistent height between experiments.

It is clear that between the configurations there is some variation in either the dimensions of the outer concrete walls, or in the amount and placement of the fissile material. There are some additional support materials as well as additional pieces of uranium for adjusting criticality. From the base configuration, slight adjustments in position, dimensions, and fuel mass were made, resulting in a large sampling of critical configurations.

The concrete reflector blocks were arranged to create an inner parallelepiped for placement of the uranium samples. The reflecting unit was designed to maintain structural integrity when separated, and to remain stable while the split table was in operation.

The experimenter's notes in the logbook indicate that after each adjustment, efforts were made to ensure even, straight, and consistent placement of the blocks. ${ }^{\text {a }}$ The blocks were not described in further detail and no further description of the placement of individual blocks was found. Shelves of aluminum sheet metal

${ }^{a}$ T he logbook mentioned "Concrete stacks are not straight!" (p. 109), “Top blocks canted” (p. 110), “Top blocks level!" (p. 110), and "Aligned blocks to the best of our ability" (p. 118).

Revision: 0

Page 4 of 36

Date: September 30, 2010 
NEA/NSC/DOC/(95)03/II

Volume II

HEU-MET-FAST-054

were positioned such that the $\mathrm{Al}$ square tubing helped align them at a consistent height between experiments, which aided in the consistent vertical positioning of the various HEU metal pieces.

The variation in the uranium pieces was described in the experimental report just through entries formatted as KENO inputs. Sketches were not found for the individual cases; just one undimensioned illustration of the generic layout of the experiment was available. The convention used by the experimenter was to describe each unique uranium configuration in the input as a separate cell. These cells were then stacked together to create each individual experimental configuration. Table 4 is a detailed description of the uranium cells used throughout the experiment and their corresponding cell numbers. If one knows the individual dimensions of the available uranium pieces (presented in Table 2), then it is easy to determine from the uranium height in Table 4 which pieces were used in tandem to alter the configuration of the experiment for each case. Those data were originally provided in Table 1 of Ref. 1 , with each cell being numbered and then dimensionally described with standard KENO style. The cell numbers were then arranged in an array to reflect their actual position in the physical array used in the experiment.

Table 4. Uranium Cells, Including Surrounding Air Space ${ }^{(a)}$ (Ref. 1).

\begin{tabular}{|c|l|c|c|c||}
\hline \hline Cell & \multicolumn{1}{|c|}{ U Description } & $\begin{array}{c}\text { Total U } \\
\text { Height, cm }\end{array}$ & $\begin{array}{c}\text { X Width, } \\
\text { cm (in.) }\end{array}$ & $\begin{array}{c}\text { Y Width } \\
\text { cm (in.) }\end{array}$ \\
\hline \hline 1 & Large Cylinder Only & 10.8 & $30.48(12)$ & $30.48(12)$ \\
\hline 2 & Small Cylinder Stacked on Large Cylinder & 13.5 & $30.48(12)$ & $30.48(12)$ \\
\hline 3 & Large Cylinder Only & 10.8 & $25.4(10)$ & $30.48(12)$ \\
\hline 4 & Small Cylinder Stacked on Large Cylinder & 13.5 & $25.4(10)$ & $30.48(12)^{(b)}$ \\
\hline 5 & Large Cylinder Only & 10.8 & $22.86(9)$ & $30.48(12)$ \\
\hline 6 & Rectangular Plate Stacked on Large Cylinder & 10.96 & $22.86(9)$ & $30.48(12)$ \\
\hline 7 & Rectangular Plate Stacked on Large Cylinder & 11.12 & $22.86(9)$ & $30.48(12)$ \\
\hline 8 & Rectangular Plates Stacked on Large Cylinder & 11.28 & $22.86(9)$ & $30.48(12)$ \\
\hline 9 & Rectangular Plate Stacked on Large Cylinder & 11.44 & $22.86(9)$ & $30.48(12)$ \\
\hline
\end{tabular}

(a) All cells were $30.48 \mathrm{~cm}$ high. The large $\mathrm{U}$ cylinder is centered in each cell, and the small $\mathrm{U}$ cylinder or $\mathrm{U}$ rectangular plates are on top of the large $U$ cylinder and centered on it. Plate sides are parallel to the surfaces of the reflector. Cylinder radii are $5.76 \mathrm{~cm}$. Plate lengths and widths are $12.7 \mathrm{~cm}$.

(b) The $\mathrm{Y}$ and $\mathrm{Z}$ dimensions of Cell 4 were not explicitly given in Ref. 1, but calculated from the data presented in Table 1 at the end of Ref. 1.

Each of the uranium units described above was placed into the reflecting unit in different combinations to provide the 14 experimental cases, shown in Table 5. The experimental report contained information regarding three more configurations, but these configurations were not considered as there is no experimental $k_{\text {eff }}$ data for these cases.

The experiment description implies that attempts were made to ensure the cylinders were centered in the overall reflecting unit, and consistently aligned between configurations. With regard to accurate spacing, Ref. 1 (p. 9) says, "The measurements of the distances separating the fissile units are averages for the 8unit arrays and are within $\pm 0.03 \mathrm{~cm}$ " for the concrete reflected arrays, and "because of roughness and irregularities in the concrete, the location of the concrete surface is known only to $\pm 0.2 \mathrm{~cm} . "$

The dimensions given in Ref. 1 and logbook sketches indicate that the large uranium cylinders were always centered in the cells of the $2 \times 2 \times 2$ array designated as the core. For all configurations, the core rests on the bottom reflector and is centered horizontally in the internal void. There is a $0.96 \mathrm{~cm}$ air space at the top that is not included in the centered air void, but is an extra gap at the top of the core. The core 


\section{NEA/NSC/DOC/(95)03/II}

Volume II

\section{HEU-MET-FAST-054}

description in the following table lists the dimensions for the array of 8 cells that fill space inside the concrete reflector, including the air space surrounding the uranium pieces.

Table 5. Core Dimensions, Experimental Layout, and Experimental $k_{\text {eff }}\left(\right.$ Ref. 1). ${ }^{(a)}$

\begin{tabular}{|c|c|c|c|c|c|c|}
\hline Exp. \# & $\begin{array}{c}\text { Bottom Cells } \\
\text { N S }\end{array}$ & $\begin{array}{c}\text { Top Cells } \\
\text { N S }\end{array}$ & $X(\mathrm{~cm})$ & $Y(\mathrm{~cm})$ & $\mathrm{Z}(\mathrm{cm})$ & $\mathbf{k}_{\text {eff }}^{(\mathbf{b})}$ \\
\hline 1 & $\begin{array}{ll}1 & 1 \\
1 & 1\end{array}$ & $\begin{array}{ll}2 & 1 \\
2 & 2\end{array}$ & 60.96 & 60.96 & 60.96 & 1.0016 \\
\hline 2 & $\begin{array}{ll}1 & 1 \\
1 & 1\end{array}$ & $\begin{array}{ll}1 & 1 \\
1 & 1\end{array}$ & 60.96 & 60.96 & 60.96 & 0.9722 \\
\hline 3 & $\begin{array}{ll}1 & 3 \\
1 & 3\end{array}$ & $\begin{array}{ll}2 & 3 \\
2 & 3\end{array}$ & 55.88 & 60.96 & 60.96 & 1.0019 \\
\hline 4 & $\begin{array}{ll}1 & 3 \\
1 & 3 \\
\end{array}$ & $\begin{array}{ll}1 & 3 \\
1 & 3 \\
\end{array}$ & 55.88 & 60.96 & 60.96 & 0.9823 \\
\hline 5 & $\begin{array}{ll}5 & 3 \\
5 & 3 \\
\end{array}$ & $\begin{array}{ll}5 & 3 \\
5 & 4 \\
\end{array}$ & 48.26 & 60.96 & 60.96 & 1.0074 \\
\hline 6 & $\begin{array}{ll}5 & 3 \\
5 & 3\end{array}$ & $\begin{array}{ll}5 & 3 \\
5 & 3\end{array}$ & 48.26 & 60.96 & 60.96 & 0.9976 \\
\hline 7 & $\begin{array}{ll}5 & 5 \\
5 & 5\end{array}$ & $\begin{array}{ll}6 & 6 \\
6 & 6\end{array}$ & 45.72 & 60.96 & 60.96 & 1.0071 \\
\hline 8 & $\begin{array}{ll}5 & 5 \\
5 & 5\end{array}$ & $\begin{array}{ll}7 & 7 \\
7 & 7\end{array}$ & 45.72 & 60.96 & 60.96 & 1.0112 \\
\hline 9 & $\begin{array}{ll}5 & 5 \\
5 & 5\end{array}$ & $\begin{array}{ll}8 & 8 \\
8 & 8\end{array}$ & 45.72 & 60.96 & 60.96 & 1.0142 \\
\hline 10 & $\begin{array}{ll}5 & 5 \\
5 & 5\end{array}$ & $\begin{array}{ll}9 & 9 \\
9 & 9\end{array}$ & 45.72 & 60.96 & 60.96 & 1.0166 \\
\hline 11 & $\begin{array}{ll}5 & 5 \\
5 & 5 \\
\end{array}$ & $\begin{array}{ll}5 & 5 \\
5 & 5 \\
\end{array}$ & 45.72 & 60.96 & 60.96 & 1.0031 \\
\hline 12 & $\begin{array}{ll}5 & 5 \\
5 & 5\end{array}$ & $\begin{array}{ll}5 & 5 \\
5 & 5\end{array}$ & 45.72 & 60.96 & 60.96 & 0.9982 \\
\hline 13 & $\begin{array}{ll}5 & 5 \\
5 & 5\end{array}$ & $\begin{array}{ll}8 & 8 \\
8 & 8\end{array}$ & 45.72 & 60.96 & 60.96 & 1.0003 \\
\hline 14 & $\begin{array}{ll}5 & 5 \\
5 & 5 \\
\end{array}$ & $\begin{array}{ll}8 & 8 \\
8 & 8 \\
\end{array}$ & 45.72 & 60.96 & 60.96 & 0.9892 \\
\hline
\end{tabular}

(a) In the two columns of cell numbers, those on the North table are on the left and those on the South table are on the right (indicated by $\mathbf{N}$ and $\mathbf{S}$ in the heading). The $\mathrm{X}$ dimension is in the North-South direction.

(b) These experimental $k_{\text {eff }}$ values are 0.0014 greater than the reported values in Ref. 1, which "have been reduced by 0.0014 to correct for the aluminum support structures" (Ref. 1, p. 6, footnote d). Therefore, these represent $k_{\text {eff }}$ of the concrete-reflected $2 \times 2 \times 2$ core array including the aluminum support structures.

As mentioned previously, only three configurations were evaluated in detail. Images of those three configurations (1, 3, and 11) are shown in Figures 1-6. 


\section{NEA/NSC/DOC/(95)03/II \\ Volume II}

\section{HEU-MET-FAST-054}

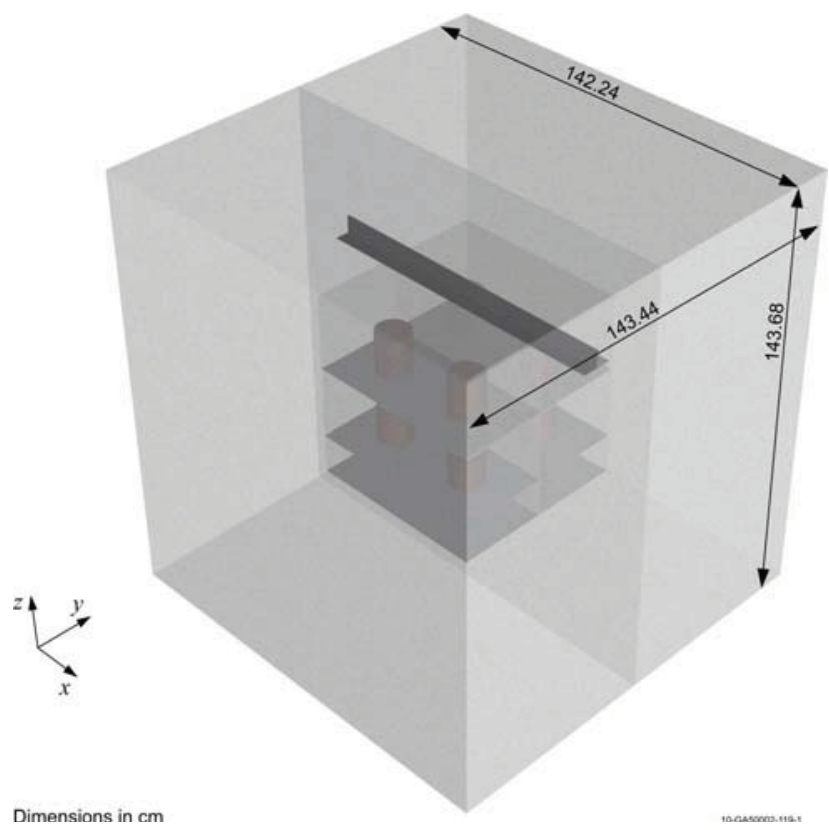

Figure 1. Experiment 1.

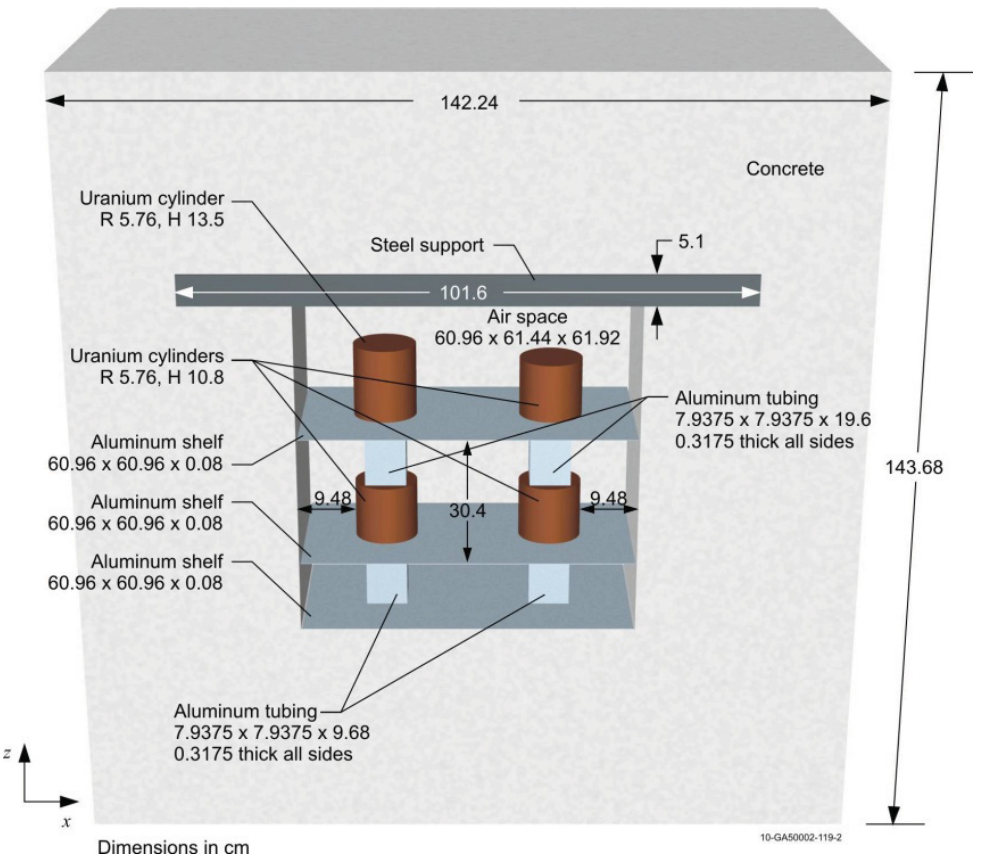

Figure 2. Experiment 1, Front View with Front Reflector Removed. 


\section{NEA/NSC/DOC/(95)03/II \\ Volume II}

\section{HEU-MET-FAST-054}

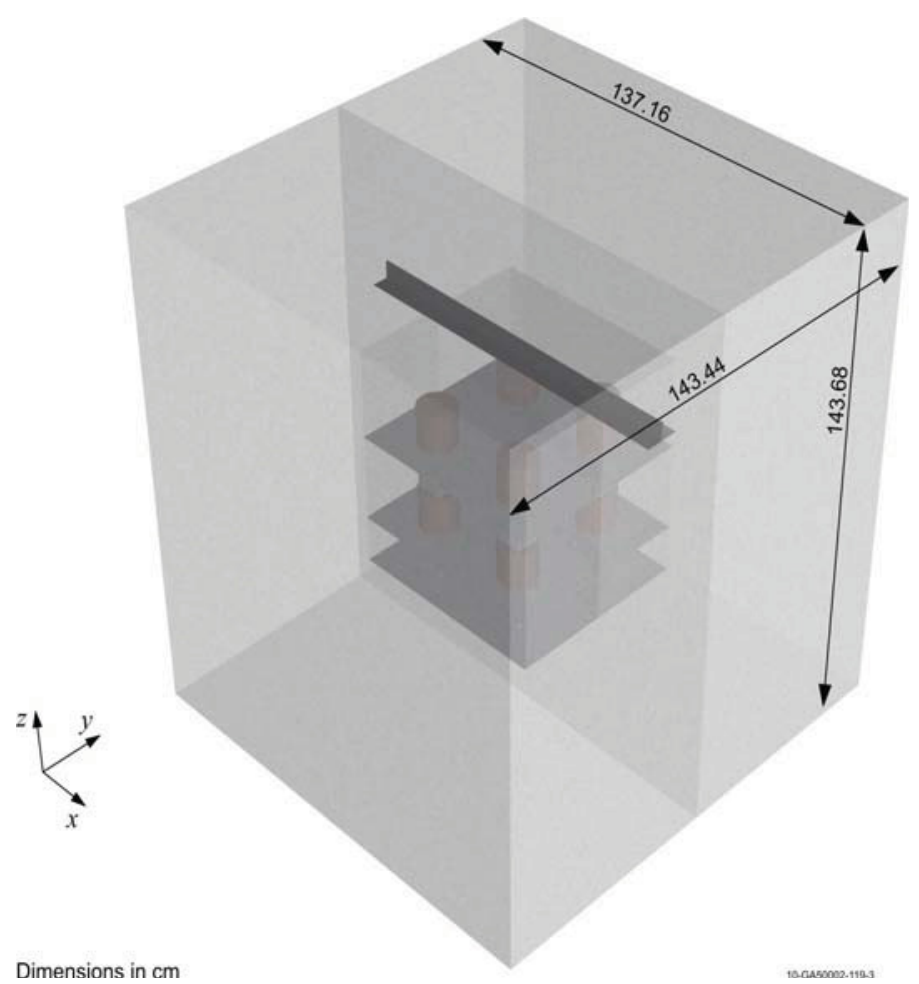

Figure 3. Experiment 3.

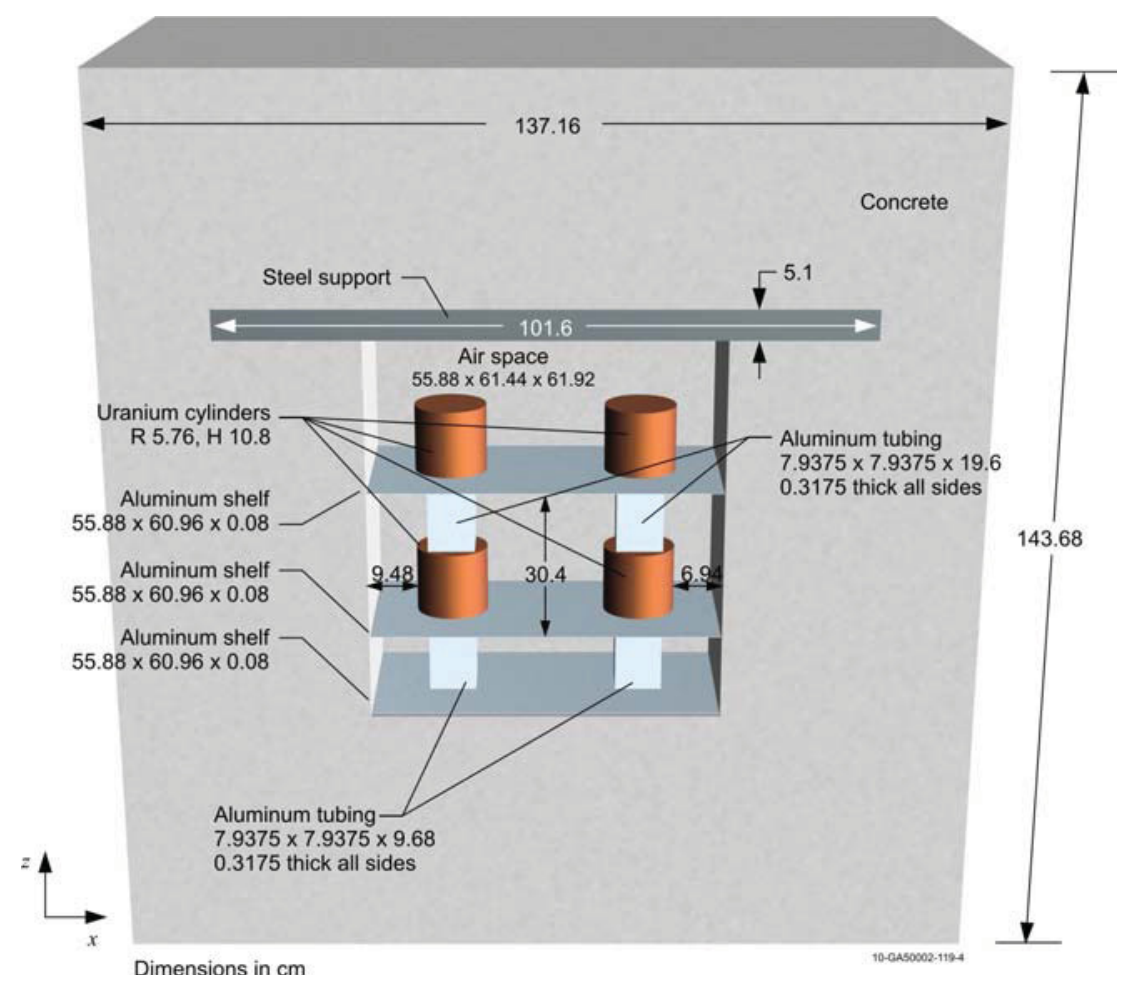

Figure 4. Experiment 3, Front View with Front Reflector Removed. 


\section{NEA/NSC/DOC/(95)03/II \\ Volume II}

\section{HEU-MET-FAST-054}

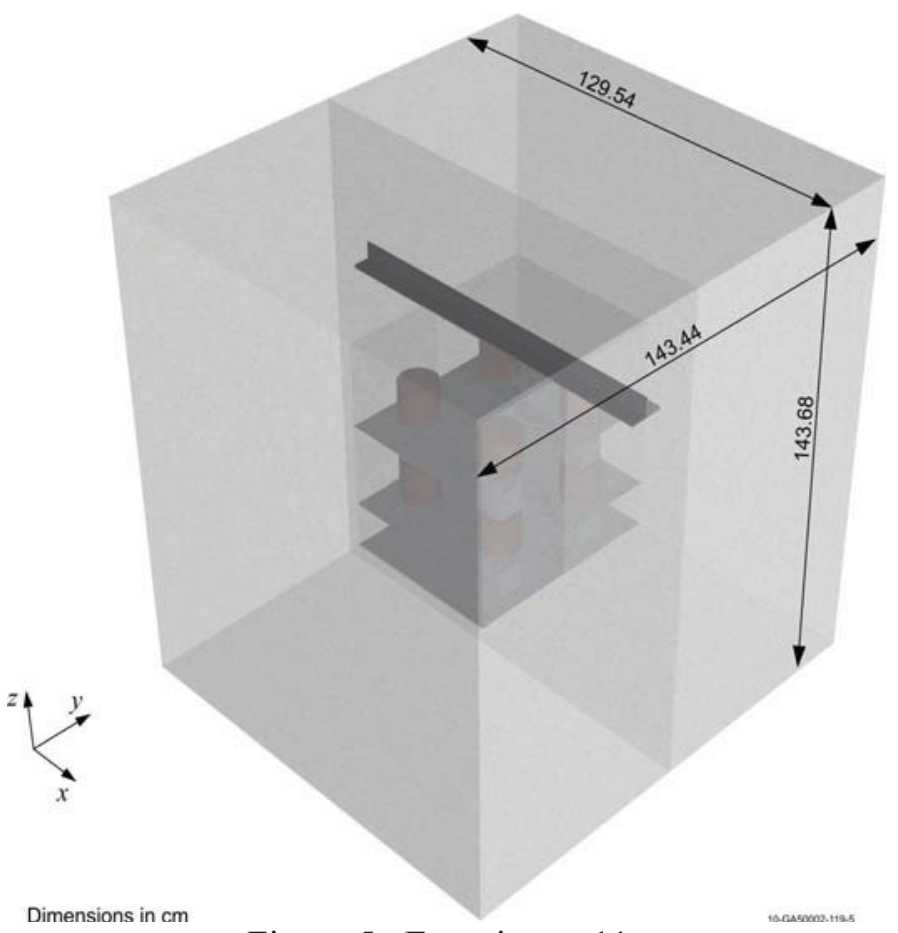

Figure 5. Experiment 11. 


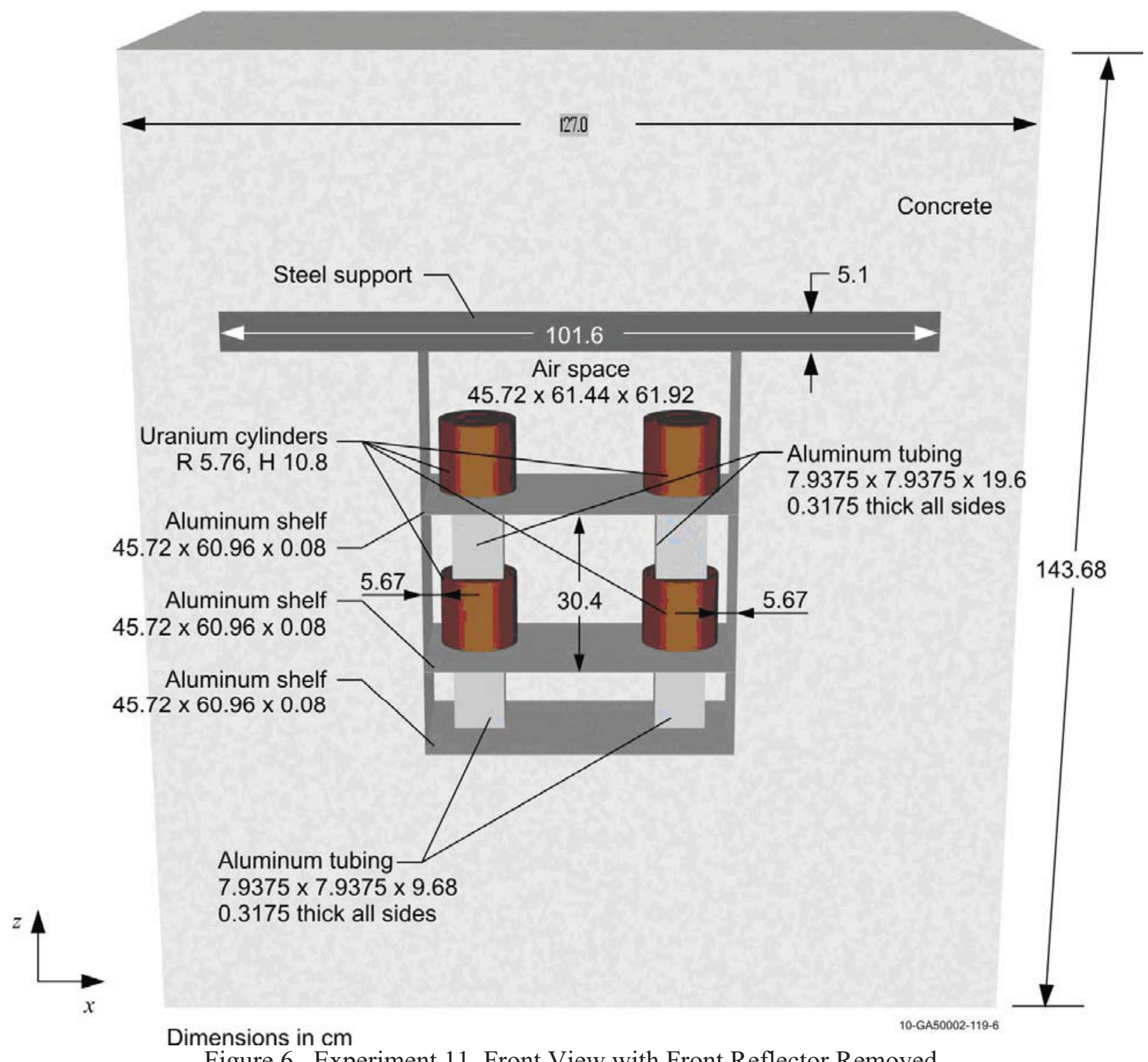

Figure 6. Experiment 11, Front View with Front Reflector Removed.

1.2.6 Measurement Procedure - It is not completely described how the experimental $\mathrm{k}_{\mathrm{eff}}$ values were determined. Logbook entries show graphs of period measurements (often without units or scales), and corresponding reactivity values in cents. Some places in the logbook note a cents per inch of table separation value, which were apparently used to determine the reactivity of each experimental configuration given in Ref. 1, both the supercritical and subcritical configurations. Details regarding the critical separation of the halves of the table, the critical gap, and extrapolation methods were not found.

\subsection{Description of Material Data}

1.3.1 Uranium - The uranium used for all the fissile pieces is $93.2 \%$ enriched metal. The eight large cylinder pairs were separated into their top and bottom halves, and each portion was individually measured, with a reported average pair weight of $20.962 \mathrm{~kg}$ (Ref. 1). This weight, along with the 
dimensions provided in Table 2, was used to determine the overall density of the cylinders, a reported value of $18.62 \mathrm{~g} / \mathrm{cm}^{3}$ (Ref. 1, 3).

The reported isotopic composition is listed in Table 6. The experimenter references other works with the same uranium cylinders as the source for the reported information (Ref. 1, p. 7).

Table 6. Uranium Composition (Ref. 1).

\begin{tabular}{|c|c|c|}
\hline Isotope & Atom Density $\left(\mathbf{c m}^{-3}\right)$ & Weight Percent \\
\hline \hline $\mathrm{U}^{234}$ & considered part of $\mathrm{U}^{238}$ & considered part of $\mathrm{U}^{238}$ \\
\hline $\mathrm{U}^{235}$ & $4.448 \mathrm{E}+22$ & 93.2 \\
\hline $\mathrm{U}^{236}$ & considered part of $\mathrm{U}^{238}$ & considered part of $\mathrm{U}^{238}$ \\
\hline $\mathrm{U}^{238}$ & $3.201 \mathrm{E}+21$ & 6.8 \\
\hline
\end{tabular}

The weight percents for $\mathrm{U}^{234}, \mathrm{U}^{235}, \mathrm{U}^{236}$, and $\mathrm{U}^{238}$ were presented in further detail in other related reports (Ref. 2 and 3); from these values, a more complete atom density calculation was completed and can be found in Table B.5.

1.3.2 Support Materials - The steel angle support is described as "stainless steel." The aluminum shelves and support tubes are reported to be constructed of aluminum.

1.3.3 Concrete - The concrete has a density reported in Ref. 1 of $2.15 \mathrm{~g} / \mathrm{cm}^{3}$. Analysis sheets, various hand calculations and spectroscopy results from lab work are included in the logbook ${ }^{\mathrm{a}}$, as well as in the experimental report. However, the different sources of data are not consistent. A concrete analysis for Magnuson dated 10-30-72 (Control No. D94278) gives a density of $100.4 \mathrm{lb} / \mathrm{ft}^{3}\left(1.608 \mathrm{~g} / \mathrm{cm}^{3}\right)$. The values given for the D94278 analysis as well as those in the analysis for Requisition No. 684639 generally agree with those calculated from the atom-density composition given in Ref. 1; in the second analysis, B (boron) is noted as $4.0 \mathrm{ppm}$. A "Sample Rerun" for this requisition number for a few elements was made. A handwritten analysis comparing the two different compositions is shown in the logbook. Some of the atomic weights used in the analysis to obtain atom densities are given. Another concrete composition analysis of non-major elements for Magnuson, Request No. 26484, dated 12-13-72, is a "Semi-Quantitative Analysis - The values reported are visual estimates taken from a standard plate and using a common graphite matrix. These values are to be interpreted as approximations only. Actual values should be within the range times $1 / 2$ to times 2." Here, boron wt. $\%$ is reported as 0.01 . A Loss-ondrying technique was used to acquire the chemical composition. The atom densities from the experimental report are presented in Table 7

a ORNL Logbook 27R, pages $208-217$. The calculation of density $2.15 \mathrm{~g} / \mathrm{cm}^{3}$ is found on page 155 and is repeated on page 217 . The density $1.61 \mathrm{~g} / \mathrm{cm}^{3}$ is found on page 212 .

Revision: 0

Page 11 of 36

Date: September 30, 2010 


\section{NEA/NSC/DOC/(95)03/II \\ Volume II}

HEU-MET-FAST-054

Table 7. Concrete Reported Composition (Ref. 1, p. 8).

\begin{tabular}{|c|c||}
\hline Element & Atom Density $\left.\mathbf{( c m}^{-3}\right)$ \\
\hline $\mathrm{H}$ & $4.24 \mathrm{E} 21$ \\
\hline $\mathrm{C}$ & $1.13 \mathrm{E} 22$ \\
\hline $\mathrm{O}$ & $4.02 \mathrm{E} 22$ \\
\hline $\mathrm{Mg}$ & $7.9 \mathrm{E} 19$ \\
\hline $\mathrm{Al}$ & $4.99 \mathrm{E} 21$ \\
\hline $\mathrm{Si}$ & $3.75 \mathrm{E} 20$ \\
\hline $\mathrm{S}$ & $1.93 \mathrm{E} 21$ \\
\hline $\mathrm{Cl}$ & $1.00 \mathrm{E} 20$ \\
\hline $\mathrm{K}$ & $1.90 \mathrm{E} 19$ \\
\hline $\mathrm{Ca}$ & $3.11 \mathrm{E} 20$ \\
\hline $\mathrm{Ti}$ & $7.27 \mathrm{E} 21$ \\
\hline $\mathrm{Mn}$ & $4.0 \mathrm{E} 19$ \\
\hline $\mathrm{Fe}$ & $1.20 \mathrm{E} 19$ \\
\hline $\mathrm{Zn}$ & $1.29 \mathrm{E} 20$ \\
\hline $\mathrm{Sr}$ & $8.9 \mathrm{E} 18$ \\
\hline $\mathrm{Ba}$ & $8.9 \mathrm{E} 18$ \\
\hline
\end{tabular}

\subsection{Supplemental Experimental Measurements}

No additional measurements were performed. 
NEA/NSC/DOC/(95)03/II

Volume II

HEU-MET-FAST-054

\subsection{EVALUATION OF EXPERIMENTAL DATA}

\subsection{Uncertainties and Inconsistencies}

Uncertainties and inconsistencies created large enough errors that all configurations were determined to be unacceptable as criticality benchmark experiments. Experimental Configurations 2, 4, 6, and 12 were precluded from the study because they were reported as very subcritical. Likewise, Configurations 5, 7, 8 , 9, and 10 were precluded because they were reported as highly supercritical and insufficient information was provided for determining critical gap or method of extrapolation to supercritical.

Some uncertainty was encountered with the description of the experimental geometry. Experiments 13 and 14 have the same description, but different resulting $\mathrm{k}_{\text {eff }}$ values and no further information was provided in any of the experiment documents. It is believed that Experiment 14 might have been formed following the same trend as the previous two experiments; however, it is also possible that this experiment was indeed the same as 13 and simply demonstrates the error in the extrapolation methods used. Both cases were discarded as there was no way to distinguish the erroneous data. Only Configurations 1, 3, and 11 were evaluated in greater detail. For the remainder of the report, these configurations are referred to as experimental Cases 1,3, and 11. Additionally, the exact orientation of the reflector overhang is not known.

The chief contributor to uncertainty was the material properties of the concrete. The density and composition both contributed to significant uncertainty in $\mathrm{k}_{\text {eff. }}$

The other notable uncertainty comes from how $k_{\text {eff }}$ values were determined. There were supercritical $k_{\text {eff }}$ values reported for several experimental cases, some even reported as prompt critical. Large extrapolations must have been made to measure these values, but there is a great lack of detail in the report and logbook concerning the exact method of measuring $k_{\text {eff. }}$ The experiments numbers used in the logbook do not match those reported in Ref 1, and not all experiments performed were reported. There were in some places records of "contact" or "concrete in contact" or "tables in contact with concrete." Some measurements of gap distance in inches are present for some experiments in the logbook, and in other places positive-period measurement in seconds were provided in other experiments. The gap distance could be either inches between the halves of the split table apparatus or at closure of the concrete reflector, it is not clear what the experimenter means by this data.

It should be noted that calculations a using Table A.1 "Reactivity (Cents) versus Asymptotic Period (Seconds) for U235" from Keepin's book entitled Physics of Nuclear Kinetics, gave reactivity values in cents that were the same as those presented in the logbook. Using a $\beta_{\text {eff }}$ of 0.0064 as indicated on p156 of the logbook gave some $\mathrm{k}_{\text {eff }}$ values close to those given in Reference 1 .

It is not clear whether tables (i.e., cells) in contact would have given a 0.0 gap value or not. In the earlier experiments, the gap value $0.1 \mathrm{in}$. was taken to indicate table halves were in contact at the plane of separation. On Nov. 14, after restacking the concrete, the gap reading was 0.148 in. with "tables in contact with concrete" (logbook experiment. \#33, p. 143), and in subsequent similar experiments this was used as the value for the closed configuration. If a 0.0 reading did indicate table contact, then the small positive gap readings at "concrete contact" would refer to a small gap between tables and thus perhaps between cells when the concrete reflectors contacted each other. It is not known whether or not the experimenter made corrections to measured reactivities to account for this gap, or how the correction might have been estimated.

a Thanks to Virginia Dean who performed these calculations and pointed out their significance.

Revision: 0

Date: September 30, 2010

Page 13 of 36 
NEA/NSC/DOC/(95)03/II

Volume II

HEU-MET-FAST-054

Besides notes taken at the time of the experiments, the logbook pages show later notes of calculations using the experimentally measured values to determine reactivity worths of configuration variations, such as thinner reflector walls and added uranium pieces. On page 156 of the logbook, there is a calculation of reactivity worth of the concrete reflector in dollars and a corresponding $\Delta \mathrm{k}_{\text {eff, }}$ which indicates a $\beta_{\text {eff }}$ of 0.0064 .

Reactivity of the aluminum structure was measured for a configuration that had a total of $16 \mathrm{Fe}$ plates (each $1 / 4 \times 4 \frac{1}{2} \times 4 \frac{1}{2}$ in.) in the 4 cells of the South table and with and without duplicate aluminum support pieces in each of the 4 cells of the North table. The calculation on page 122 of the logbook shows the worth of the aluminum support structure in 8 cells to be 21.8 cents. This 21.8 -cent value is shown in other calculations in the logbook, notably in what appears to be the calculation for $\mathrm{k}_{\text {eff }}$ of Case 11 . Using $\beta_{\text {eff }}$ of 0.0064 shown on this same page ${ }^{\mathrm{a}}$ gives $\Delta \mathrm{k}_{\text {eff }}$ of 0.0014 , the value given in Ref. 1 (footnote $\mathrm{d}$ on $\mathrm{p}$. 6) for the aluminum support structure.

It appears that calculated worths were similarly added and subtracted, as appropriate, perhaps with estimates of corrections, to a measured reactivity to obtain the "experimental" worths of the configurations reported in Ref. 1. Such worths depend on the particular configurations for which they were measured, but the methods of determining and adding the worths were not formally described, so that uncertainties could not be estimated, another reason these experiments were determined to be unacceptable as a benchmark. Without this information, there is no reliable way to model or derive benchmark specifications for several of the experimental configurations.

Effects of uncertainties in material composition of the uranium, as well as in uranium mass, density, and dimensions were judged to be insignificant compared to other uncertainties associated with these experiments, based on the effects of similar uncertainties observed in previous benchmark reports that use the same HEU cylinders.

2.1.1 Concrete Uncertainties - The experimenter used chemical and spectrographic analyses to obtain the reported composition of the concrete reflector. Dates on the analysis reports and in the logbook indicate that the experiments and the analyses were all done at about the same time - within a period of about two months (mid October to mid December of 1972). The dates were given on the concretecomposition analysis sheets found in the logbook. The dates on the "original" analysis sheets (logbook pages 182-3) say 10-28-72 and 10-30-72, or about 2 weeks before the experiments. Also, reanalysis of a few elements was apparently requested after a comparison of the results from 2 different analyses showed large differences for a couple of elements; the revised results were in better agreement. The last analysis date was $12-15-72^{\mathrm{b}}$ for only one compound, $\mathrm{SiO}_{2}$. The next latest was a spectrographic analysis on 1213-72. ${ }^{\mathrm{c}}$ The atom densities from the experimental report were presented in Table 7 , and this is the composition data selected for use in this evaluation.

It appears that all concrete analyses were done within about a month of the date of the experiments. However, concrete continues to dry and react depending on its environment after it has set, ${ }^{\mathrm{d}}$ so these variations may be within normal limits. The technique used was a loss-on-drying method, as recorded in the experimental logbook. ${ }^{\mathrm{e}}$ The loss-on-drying measurement is subject to great error. As a rough approximation, a suggested possible $1 \sigma$ error of $25-30 \%$ or more is fairly standard in concrete industry

\footnotetext{
a Logbook 27 r, page 137 . (The value for $\beta_{\text {eff }}$ could possibly be 0.0069 ; it is not clearly written.)

${ }^{b}$ Logbook 27r, page 177

${ }^{c}$ Logbook 27r, page 185

d Personal communication with Ken Gilliam, former director of research for Medusa Concrete. July, 2009.

${ }^{\mathrm{e}}$ Logbook 27R, page 182.

Revision: 0

Date: September 30, 2010

Page 14 of 36
} 
measurements. ${ }^{a}$ Following this guideline, the hydrogen content of the Magnuson concrete was varied in calculations by $\pm 30 \%$. Decreasing the hydrogen content by $30 \%$ resulted in an average effect in the change of $\mathrm{k}_{\mathrm{eff}}$ of $+1.667 \%$. A $30 \%$ increase in the hydrogen content resulted in an effect of only $-0.621 \%$. These trends can be observed in Figure 7. Note that the water reflected case indicates that all concrete was replaced with a pure water reflector in the calculation.

Another uncertainty is the concrete density. One chemical analysis gave the density as $100.4 \mathrm{lb} / \mathrm{ft}^{3}$ $\left(1.60825 \mathrm{~g} / \mathrm{cm}^{3}\right)$ while the other spectrochemical analysis did not include a density determination. One density calculation in the logbook $\mathrm{k}^{\mathrm{b}}$ gave $2.0764 \mathrm{~g} / \mathrm{cm}^{3}$, from 360 blocks weighing 7 tons $(14000 \mathrm{lbs}$, or $6350.3 \mathrm{~kg}$ ). The given density of $2.15 \mathrm{~g} / \mathrm{cm}^{3}$ found in Ref. 1 agrees with the second calculation in the logbook of density from the weight of 10 blocks, given as $18.314 \mathrm{~kg}$. Using the density from the chemical analysis, 10 blocks of exactly the nominal specifications of $4^{\prime \prime} \times 8^{\prime \prime} \times 16^{\prime \prime}$ would weigh $13.494 \mathrm{~kg}$. However, actual weight might have been a little less due to lower density of the block surfaces compared to the analysis density. If the actual average weight of a block from weighing the 10 blocks was, for example, $13.314 \mathrm{~kg}$ (instead of $18.314 \mathrm{~kg}$, with the first " 3 " mistaken for an " 8 "), then density of the stacked blocks would be $1.56393 \mathrm{~g} / \mathrm{cm}^{3}$, which is much closer to the laboratory-measured density. There is nothing in the report, except the discrepancy itself, which indicates this may have happened, so assuming that this happened cannot be validated. All that can be said is that there is a large discrepancy between lab-analysis density $\left(1.61 \mathrm{~g} / \mathrm{cm}^{3}\right)$ and calculated density $\left(2.15 \mathrm{~g} / \mathrm{cm}^{3}\right)$. The calculated effect of concrete density being $1.61 \mathrm{~g} / \mathrm{cm}^{3}$ rather than $2.15 \mathrm{~g} / \mathrm{cm}^{3}$ indicates a large effect from concrete-density uncertainty. The average calculated effect on the change in $\mathrm{k}_{\text {eff }} \mathrm{was}+2.29 \%$.

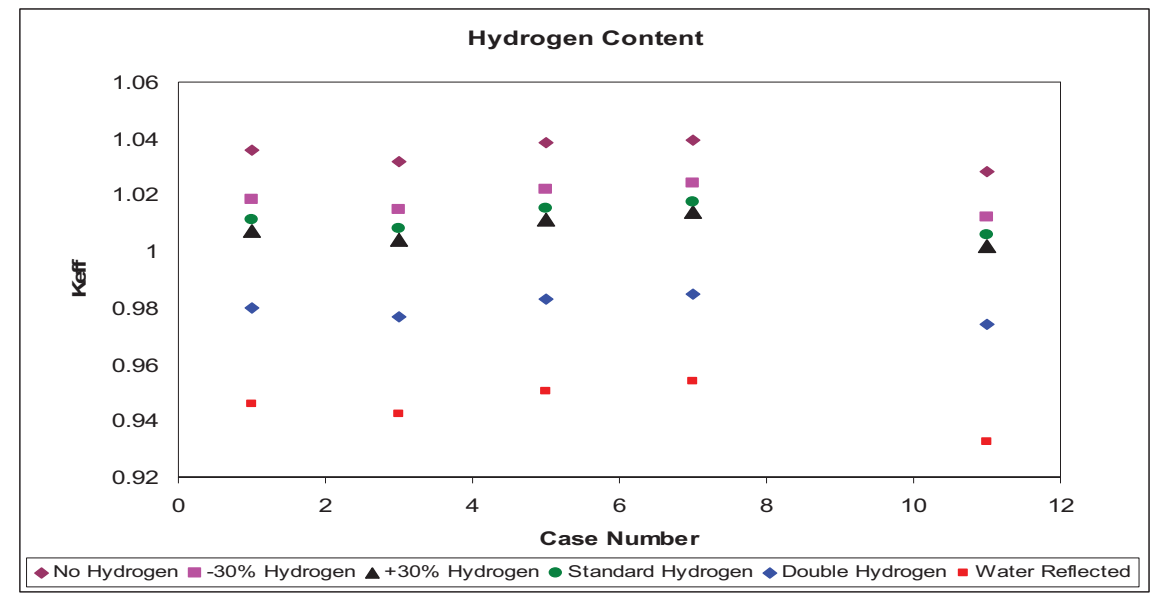

Figure 7. Hydrogen Content Sensitivity.

Lastly, there is some uncertainty in the geometric arrangement of the concrete blocks. A small overhang protrudes from the top and bottom reflector, which is clearly illustrated in the sketch on page 106 of the logbook. This image shows the overhang orientation with respect to the placement of the concrete cylinders. There is a second sketch on p105, which also shows the overhang, and additionally labels the east and west direction of the experiment, but does not show the orientation of the uranium cylinders in the experiment. The experimenter also lists measured sizes of the north and south halves of the experiments in several pages of the logbook. Depending on the interpretation of the layout of the sketches and the grouping of the listed measurements, the direction of the overhang and the orientation of the steel angle support could be interpreted to be perpendicular to the orientation shown in the figures in

\footnotetext{
a Personal communication with Dr. Avi Mor, owner of Dr. Mor \& Associates. June 2009.

b Page 123. Both calculations of density are on this logbook page. 
the report. However, neither the orientation of the overhang nor the steel support will affect the final results of this benchmark evaluation, as the bias created for either issue is negligible.

2.1.2 Uranium Cylinder Uncertainties - These cylinders have already been addressed in other benchmarks reports, and repeat calculations were not performed for this evaluation. The effects of $1 \sigma$ variations in the large uranium cylinders' density, material composition, and dimensions were evaluated in HEU-MET-FAST-053. Where values were not available in the report or experimental logbook, methods to calculate the $1 \sigma$ uncertainty for a given measurement were explained. According to Table 15 of the HEU-MET-FAST-053 evaluation, the change in $\mathrm{k}_{\mathrm{eff}}$ due to mass uncertainty as well as for isotopic concentration was found to be 0.0002 , and the change in $\mathrm{k}_{\text {eff }}$ for the dimensional uncertainty was 0.0003 or 0.0004 . It is believed that uncertainty from these areas would be similarly small for these experiments, especially when compared to the uncertainties introduced by the concrete composition. For this reason, repeat calculations were not performed.

\subsection{Unacceptability of Cases}

There were a certain number of cases removed from consideration before evaluation began due to being very subcritical or supercritical. However, at the completion of this evaluation, it has been determined that the uncertainty in the concrete precludes all cases from acceptability. Table 8 is the summary of uncertainties for these experiments.

Table 8. Uncertainties. ${ }^{(a)}$

\begin{tabular}{|c|c||}
\hline Parameter & Associated Uncertainty $^{(\mathbf{b})}$ \\
\hline \hline HEU composition, mass, density, and dimensions & Negligible \\
\hline Aluminum composition, mass, density, and dimensions & Negligible \\
\hline Steel composition, mass, density, and dimensions & Negligible \\
\hline Concrete Composition & $0.658 \% \Delta \mathrm{k}$ \\
\hline Concrete Density & $1.324 \% \Delta \mathrm{k}$ \\
\hline Total Uncertainty & $1.982 \% \Delta \mathrm{k}$ \\
\hline
\end{tabular}

(a) Note that there are potentially significant additional uncertainties as this does not include any uncertainties from the unexplained method of determining reactivity worths, nor any uncertainties associated with the gap between tables at the center of the assembly when concrete reflectors were in contact.

(b) The total uncertainty was the sum of the concrete uncertainties, as they are correlated. The concrete uncertainties were actually maximum variations and were therefore divided by the square root of 3 to obtain these $1 \sigma$ uncertainties.

No further geometric, dimensional or material uncertainties were analyzed because it was clear that the experiments were unacceptable based on the uncertainties of the concrete and the lack of critical extrapolation data. 
NEA/NSC/DOC/(95)03/II

Volume II

HEU-MET-FAST-054

\subsection{BENCHMARK SPECIFICATIONS}

None of the 14 configurations are acceptable as a criticality safety benchmark experiment; therefore benchmark models are not provided in this section. However, models were created for several of the experiments during this evaluation, and are included in Appendix B. 
NEA/NSC/DOC/(95)03/II

Volume II

HEU-MET-FAST-054

\subsection{RESULTS OF SAMPLE CALCULATIONS}

None of the 14 configurations are acceptable as a criticality safety benchmark experiment; therefore sample results are not provided in this section. However, calculation results for selected experiments were obtained during the evaluation process and are provided in Appendix B. 
NEA/NSC/DOC/(95)03/II

Volume II

HEU-MET-FAST-054

\subsection{REFERENCES}

1. Magnuson, D.W., Y-DR-109, "Critical Three Dimensional Arrays of Neutron Interacting Units, Part IV: Arrays of U(93.2) Metal Reflected by Concrete and Arrays Separated by Vermiculite and Reflected by Polyethylene," 1973.

2. Thomas, J.T., ORNL-TM-868, "Critical Three Dimensional Arrays of Neutron Interacting Units, Part II: U(93.2) Metal,” 1964.

3. Magnuson, D.W., Y-DR-83, "Critical Three Dimensional Arrays of Neutron Interacting Units, Part III: Arrays of U(92.3) Metal Separated by Various Materials," 1972. 
NEA/NSC/DOC/(95)03/II

Volume II

HEU-MET-FAST-054

\section{APPENDIX A: TYPICAL INPUT LISTINGS}

None of the 14 configurations are acceptable as a criticality safety benchmark experiment; therefore benchmark models are not provided in this section. However, typical input listings for the models described in Appendix B are included in Appendix C. 
NEA/NSC/DOC/(95)03/II

Volume II

HEU-MET-FAST-054

\section{APPENDIX B: MODELS OF SELECTED CONFIGURATIONS}

This appendix contains descriptions of the detailed models of selected experimental configurations that were developed as part of the evaluation process. They are included in this appendix to preserve perhaps useful information concerning the evaluation of these experiments. Although none are judged to be acceptable as criticality safety benchmark experiments, the models may be useful to users of the ICSBEP Handbook.

\section{B.1 Description of Model}

B.1.1 Simplification - Some efforts at simplification were felt necessary when creating the benchmark model. The lips of concrete were removed to create an even outer reflector. The calculated effects of the lips, or overhang, are given in Table B.1. The uncertainty in the position of the concrete overhang is less than the bias for removing it, and so was not considered any further for this benchmark evaluation.

A possible alternative description of the orientation of the $\mathrm{X}$ and $\mathrm{Y}$ axes with respect to the split between tables is included in Appendix D, for completeness.

Table B.1. Concrete Lip Bias. ${ }^{(a)}$

\begin{tabular}{|c|c|c|}
\hline $\begin{array}{c}\text { Configuration } \\
\text { Number }\end{array}$ & 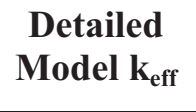 & $\begin{array}{c}\text { No Concrete Edges } \\
(\Delta \mathbf{k})\end{array}$ \\
\hline 1 & 1.01126 & -0.00018 \\
\hline 2 & 0.97956 & -0.00001 \\
\hline 3 & 1.00802 & 0.00003 \\
\hline 4 & 0.98753 & 0.00005 \\
\hline 5 & 1.01525 & -0.00018 \\
\hline 6 & 1.00596 & -0.00008 \\
\hline 7 & 1.01761 & -0.00005 \\
\hline 8 & 1.01871 & -0.00013 \\
\hline 9 & 1.02054 & -0.00015 \\
\hline 10 & 1.0209 & 0.00002 \\
\hline 11 & 1.00581 & -0.00017 \\
\hline 12 & 1.00577 & -0.00013 \\
\hline
\end{tabular}

(a) All Monte Carlo calculations had an associated $1 \sigma$ of 0.00006

B.1.2 Dimensions - The overall layout of each model is a $2 \times 2 \times 2$ array of HEU cylinders placed inside a cubic reflector constructed of concrete. The large uranium cylinders were placed one in each of the four quadrants inside the reflector, and the concrete reflector dimensions are varied between experiments, as shown in Table B.3. For certain configurations, additional uranium pieces are placed atop the standard $10.8 \mathrm{~cm}$ high uranium cylinders. The additional pieces include smaller cylinders with a height of $2.7 \mathrm{~cm}$ and uranium square plates, $12.7 \times 12.7 \mathrm{~cm}$, with varying heights. All the cylinders have a radius of 5.76 $\mathrm{cm}$. The uranium pieces are summarized in Table B.2. 
NEA/NSC/DOC/(95)03/II

Volume II

HEU-MET-FAST-054

Table B.2. Dimensions of Uranium Pieces and Cells.

\begin{tabular}{|c|l|c|c|c|c||}
\hline $\begin{array}{c}\text { Cell } \\
\text { Number }\end{array}$ & \multicolumn{1}{|c|}{ Description } & $\begin{array}{c}\text { Radius } \\
(\mathbf{c m})\end{array}$ & $\begin{array}{c}\text { Total Height } \\
\text { (a) }\end{array}$ & $\begin{array}{c}\text { Cell X } \\
\text { Width } \\
\text { (cm) }\end{array}$ & $\begin{array}{c}\text { Cell Y } \\
\text { Length } \\
\text { (cm) }\end{array}$ \\
\hline \hline 1 & Large Cylinder Only & 5.76 & 10.8 & 30.48 & 30.48 \\
\hline 2 & Stacked Large and Small Cylinders & 5.76 & 13.5 & 30.48 & 30.48 \\
\hline 3 & Large Cylinder Only & 5.76 & 10.8 & 25.4 & 30.48 \\
\hline 4 & Stacked Large and Small Cylinders & 5.76 & 13.5 & 25.4 & 30.48 \\
\hline 5 & Large Cylinder Only & 5.76 & 10.8 & 22.86 & 30.48 \\
\hline 6 & $\begin{array}{l}12.7-c m \text { Square Plate Stacked on Large } \\
\text { Cylinder }\end{array}$ & na & 10.96 & 22.86 & 30.48 \\
\hline 7 & $\begin{array}{l}12.7-\mathrm{cm} \text { Square Plate Stacked on Large } \\
\text { Cylinder }\end{array}$ & na & 11.12 & 22.86 & 30.48 \\
\hline 8 & $\begin{array}{l}12.7-\mathrm{cm} \text { Square Plate Stacked on Large } \\
\text { Cylinder }\end{array}$ & na & 11.28 & 22.86 & 30.48 \\
\hline 9 & $\begin{array}{l}12.7-\mathrm{cm} \text { Square Plate Stacked on Large } \\
\text { Cylinder }\end{array}$ & na & 11.44 & 22.86 & 30.48 \\
\hline
\end{tabular}

(a) The Total Height dimension refers to both the cylinder and plate combined.

For each of the configurations evaluated, several different permutations of the concrete reflector were incorporated into the model. A summary of the inner and outer reflector dimensions are listed in Table B.3. The cells in the core array and the core array outer dimensions were given in Table 5. The overhand of the concrete reflector is not modeled, because the bias in this lip was determined to be negligible.

Table B.3. Reflector Dimensions (Ref. 1).

\begin{tabular}{|c|c|c|c|c|c|c||}
\hline $\begin{array}{c}\text { Configuration } \\
\text { Number }\end{array}$ & $\begin{array}{c}\text { Inner X } \\
\text { Dimension }\end{array}$ & $\begin{array}{c}\text { Inner Y } \\
\text { Dimension }\end{array}$ & $\begin{array}{c}\text { Inner Z } \\
\text { Dimension }\end{array}$ & $\begin{array}{c}\text { Outer X } \\
\text { Dimension }\end{array}$ & $\begin{array}{c}\text { Outer Y } \\
\text { Dimension }\end{array}$ & $\begin{array}{c}\text { Outer Z } \\
\text { Dimension }\end{array}$ \\
\hline \hline 1 & 60.96 & 61.44 & 61.92 & 142.24 & 143.44 & 143.68 \\
\hline 2 & 60.96 & 61.44 & 61.92 & 142.24 & 143.44 & 143.68 \\
\hline 3 & 55.88 & 61.44 & 61.92 & 137.16 & 143.44 & 143.68 \\
\hline 4 & 55.88 & 61.44 & 61.92 & 137.16 & 143.44 & 143.68 \\
\hline 5 & 48.26 & 61.44 & 61.92 & 129.54 & 143.44 & 143.68 \\
\hline 6 & 48.26 & 61.44 & 61.92 & 129.54 & 143.44 & 143.68 \\
\hline 7 & 45.72 & 61.44 & 61.92 & 127.00 & 143.44 & 143.68 \\
\hline 8 & 45.72 & 61.44 & 61.92 & 127.00 & 143.44 & 143.68 \\
\hline 9 & 45.72 & 61.44 & 61.92 & 127.00 & 143.44 & 143.68 \\
\hline 10 & 45.72 & 61.44 & 61.92 & 127.00 & 143.44 & 143.68 \\
\hline 11 & 45.72 & 61.44 & 61.92 & 127.00 & 143.44 & 143.68 \\
\hline 12 & 45.72 & 61.44 & 61.92 & 106.68 & 143.44 & 143.68 \\
\hline 13 & 45.72 & 61.44 & 61.92 & 127.00 & 102.44 & 123.24 \\
\hline 14 & 45.72 & 61.44 & 61.92 & 127.00 & 102.44 & 123.24 \\
\hline
\end{tabular}




\section{NEA/NSC/DOC/(95)03/II \\ Volume II}

\section{HEU-MET-FAST-054}

The three modeled configurations were very similar; only slight changes in dimensions of the concrete and/ or uranium created the unique cases. Configuration 1 is illustrated in the following figures, as well as Configurations 3 and 11.

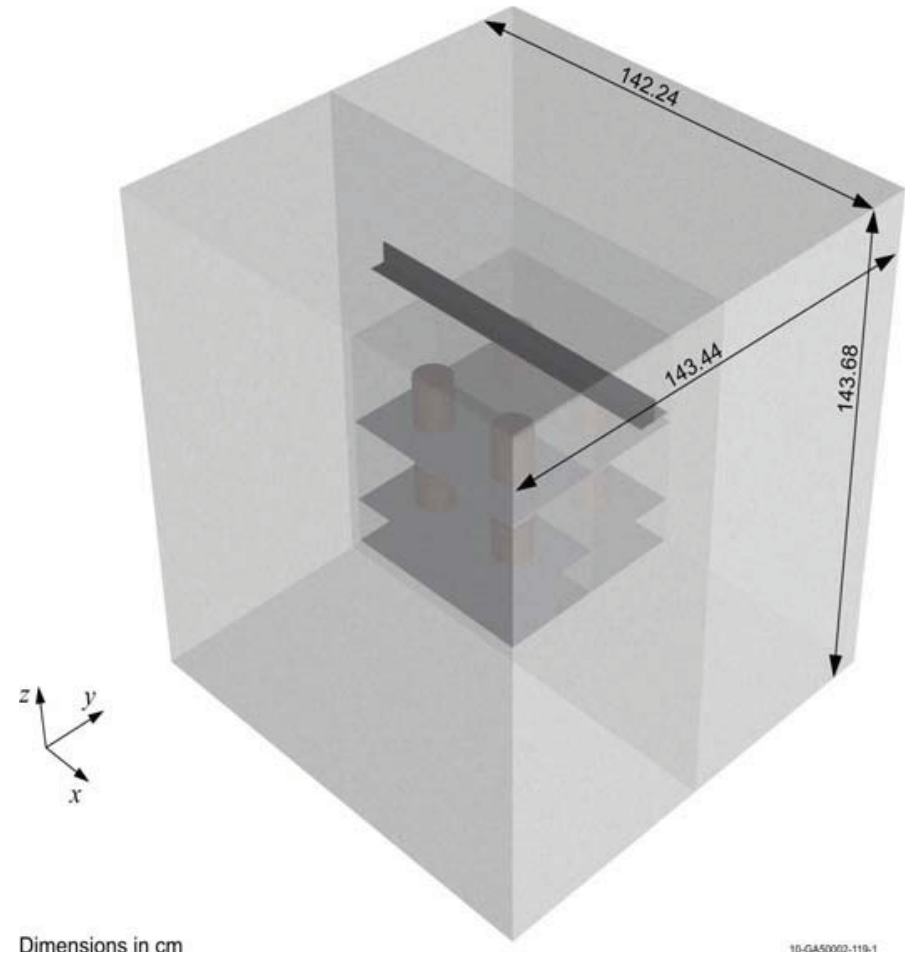

Figure B.1. Experiment 1.

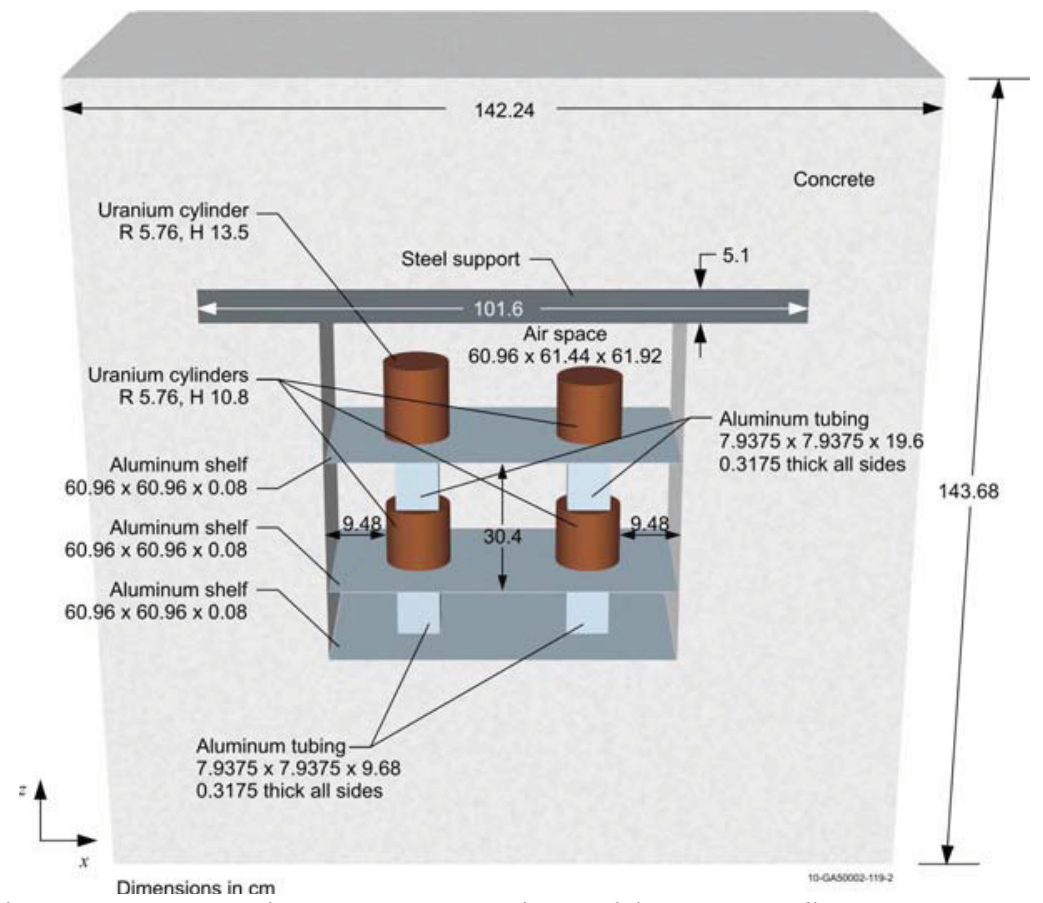

Figure B.2. Experiment 1, Front View with Front Reflector Removed. 


\section{NEA/NSC/DOC/(95)03/II \\ Volume II}

\section{HEU-MET-FAST-054}

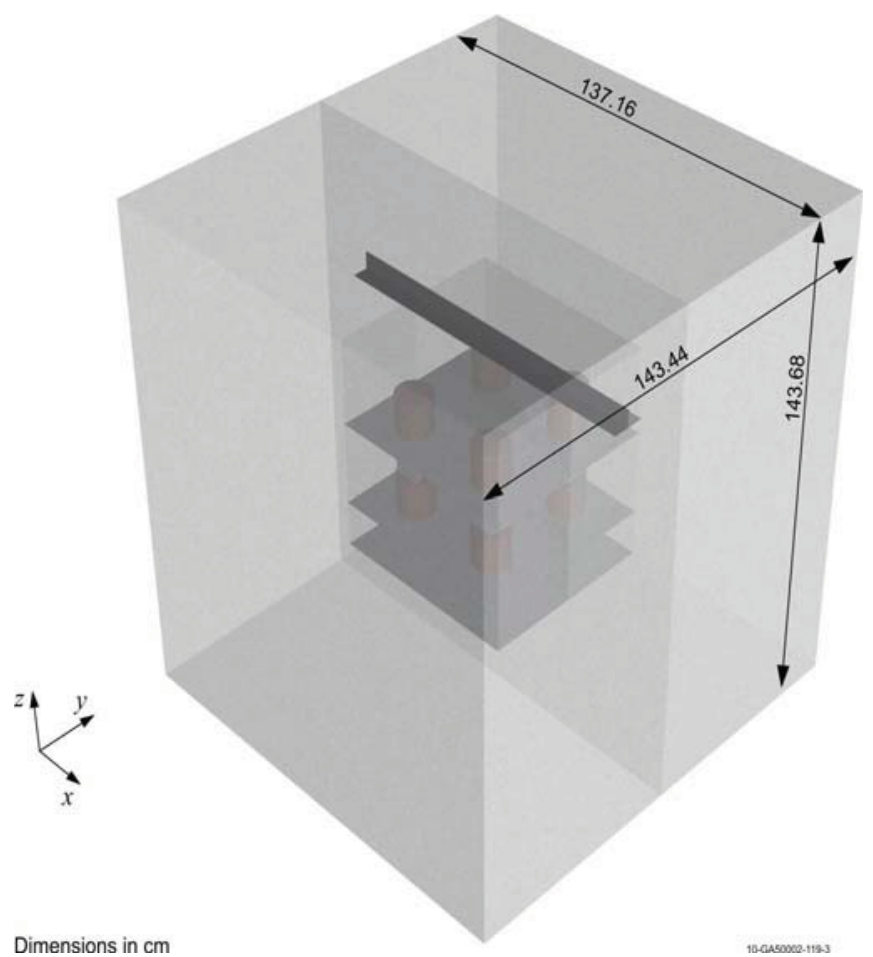

Figure B.3. Experiment 3.

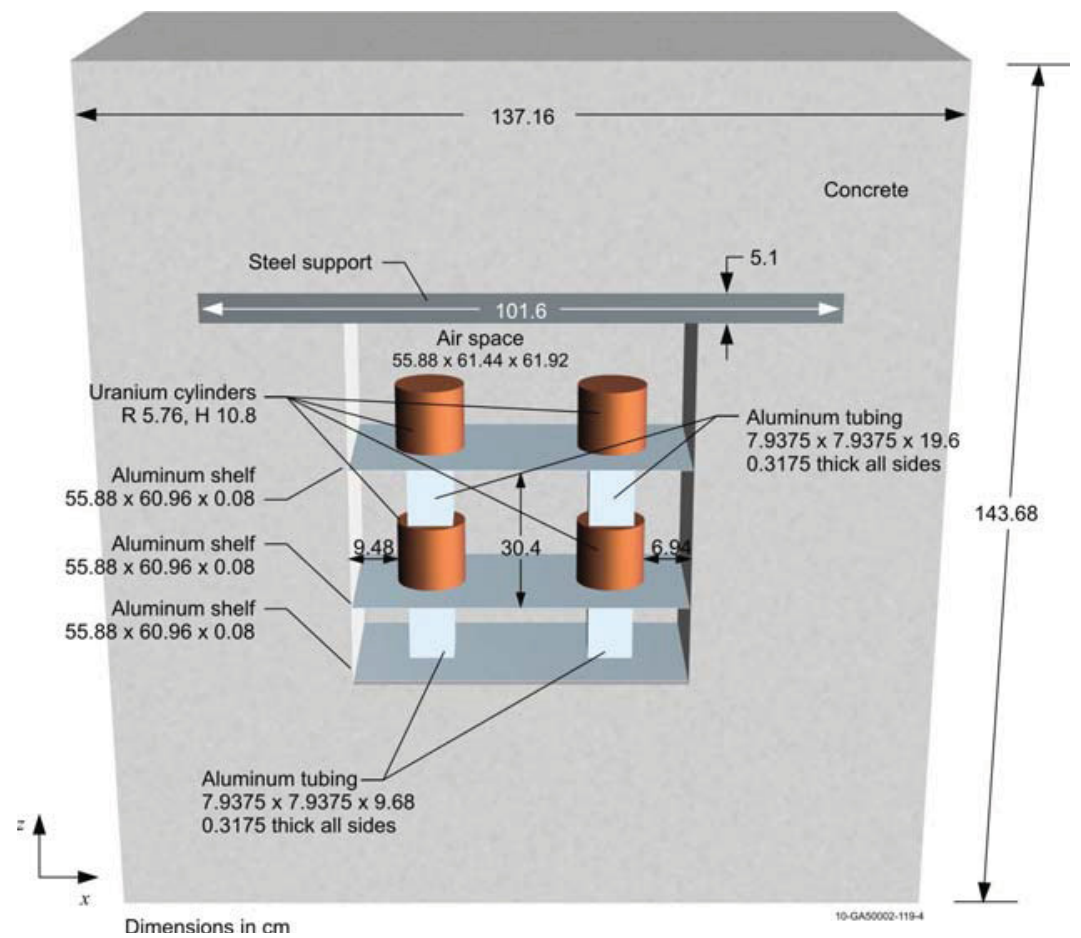

Figure B.4. Experiment 3, Front View with Front Reflector Removed. 


\section{NEA/NSC/DOC/(95)03/II \\ Volume II}

\section{HEU-MET-FAST-054}

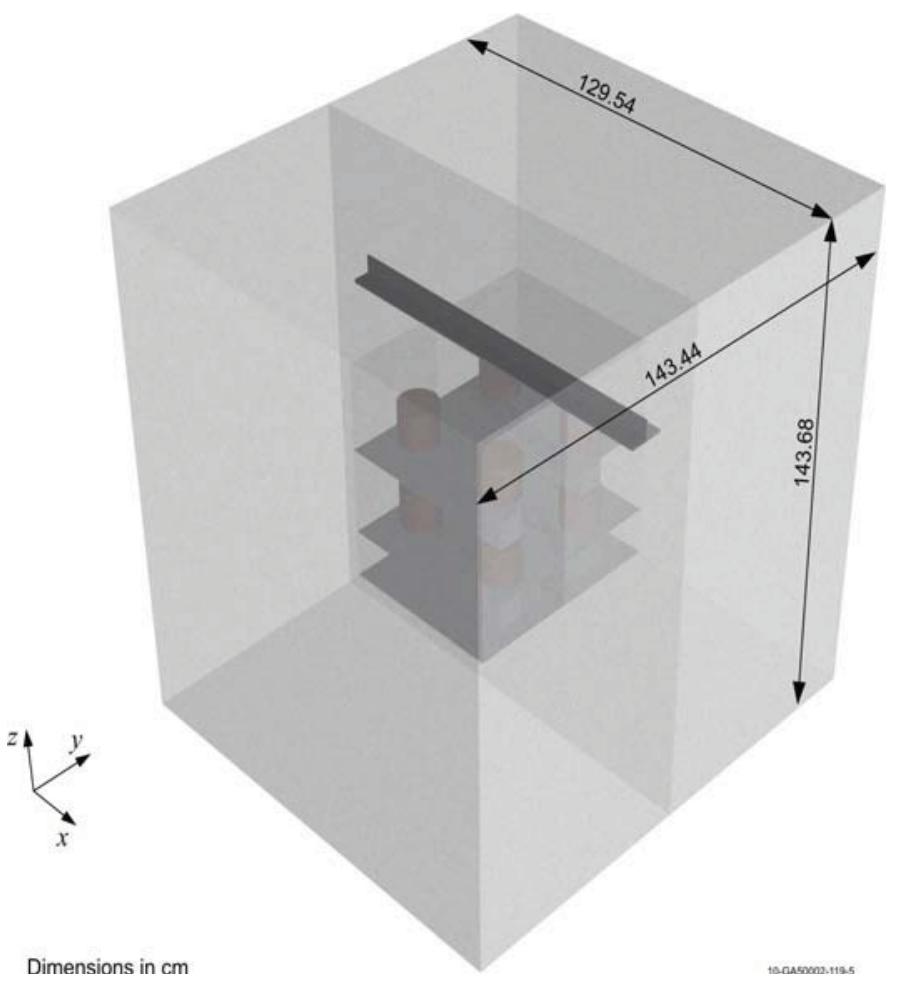

Dimensions in $\mathrm{cm}$

Figure B.5. Experiment 11.

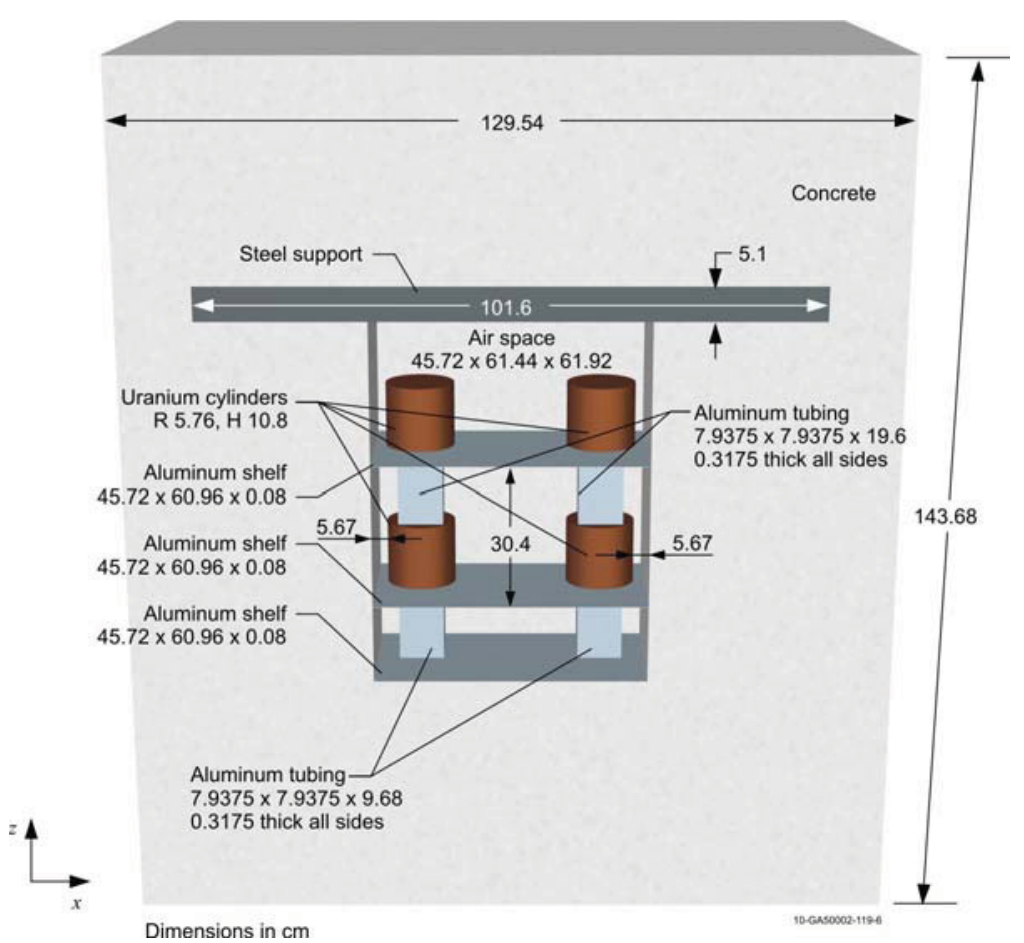

Figure B.6. Experiment 11, Front View with Front Reflector Removed. 


\section{B.2 Materials}

B.2.1 Uranium - The only fissile unit for which a detailed material description is provided is that of the large cylinders; it is assumed that the material data are the same for the smaller cylinders and the plates. The eight large cylinder pairs of $93.2 \%$ enriched uranium metal were separated into their top and bottom halves, and each portion was individually measured, with a reported average weight of $20.962 \mathrm{~kg}$. This weight, along with the dimensions provided in Table B.3, was used to determine that the overall density of the cylinders is $18.62 \mathrm{~g} / \mathrm{cm}^{3}$.

From the calculated density, the atom densities of the different uranium isotopes were then calculated by the experimenters. During these calculations, $\mathrm{U}^{234}$ and $\mathrm{U}^{236}$ were considered to be $\mathrm{U}^{238}$. The reported atom densities are listed in Table B.4.

Table B.4. Y-DR-109 Uranium Atom Densities.

\begin{tabular}{|c|c|}
\hline Isotope & Atom Density $\left(\mathbf{c m}^{-3}\right)$ \\
\hline $\mathrm{U}^{234}$ & considered part of $\mathrm{U}^{238}$ \\
\hline $\mathrm{U}^{235}$ & $4.448 \mathrm{E}+22$ \\
\hline $\mathrm{U}^{236}$ & considered part of $\mathrm{U}^{238}$ \\
\hline $\mathrm{U}^{238}$ & $3.201 \mathrm{E}+21$ \\
\hline
\end{tabular}

As mentioned previously, these fissile units have been used in other experiments, and the weight percents for $\mathrm{U}^{234}, \mathrm{U}^{235}, \mathrm{U}^{236}$, and $\mathrm{U}^{238}$ were presented in further detail in other related reports (Ref 1. and 2), from these values, a more complete atom density calculation was completed. The detailed weight percents and calculated atom densities from ORNL-TM-868 can be found in Table B.5, and these values were used when creating the detailed models.

Table B.5. Detailed Uranium Data (Ref. 2).

\begin{tabular}{|c|c|c||}
\hline Isotope & Wt.\% & $\begin{array}{c}\text { Atom Density } \\
\text { (barn-cm) }^{-1}\end{array}$ \\
\hline \hline $\mathrm{U}^{234}$ & 1.0 & $4.7911 \mathrm{E}-04$ \\
\hline $\mathrm{U}^{235}$ & 93.2 & $4.4463 \mathrm{E}-02$ \\
\hline $\mathrm{U}^{236}$ & 0.2 & $9.5008 \mathrm{E}-05$ \\
\hline $\mathrm{U}^{238}$ & 5.6 & $2.6378 \mathrm{E}-03$ \\
\hline
\end{tabular}

B.2.2 Concrete - The majority of the uncertainty in these experiments is in the concrete composition analysis. The experimenter used a chemical analysis to obtain the reported composition of the concrete reflector. The technique used was a loss-on-drying method, as recorded in the experimental logbook. (See Sections 1.3.3 and 2.1.1.) Table B.6 lists the concrete composition used in the case model. The isotope densities were calculated by the evaluator from the reported atom densities in Table 7. 


\section{NEA/NSC/DOC/(95)03/II}

Volume II

HEU-MET-FAST-054

Table B.6. Concrete Composition.

\begin{tabular}{|c|c|c|c|}
\hline Element & $\begin{array}{c}\text { Atom Density } \\
\text { (barn-cm) }^{-1}\end{array}$ & Element & $\begin{array}{l}\text { Atom Density } \\
\text { (barn-cm) }^{-1}\end{array}$ \\
\hline $2 \mathrm{H}^{1}$ & 4.2395E-03 & $\mathrm{Ca}^{44}$ & $9.8145 \mathrm{E}-06$ \\
\hline $\mathrm{H}^{2}$ & $4.8760 \mathrm{E}-07$ & $\mathrm{Ca}^{46}$ & $1.5165 \mathrm{E}-04$ \\
\hline $\mathrm{C}$ & $1.1300 \mathrm{E}-02$ & $\mathrm{Ca}^{48}$ & $2.9080 \mathrm{E}-07$ \\
\hline $\mathrm{O}^{16}$ & $4.0185 \mathrm{E}-02$ & $\mathrm{Ti}^{46}$ & $1.3595 \mathrm{E}-05$ \\
\hline $\mathrm{O}^{17}$ & $1.5276 \mathrm{E}-05$ & $\mathrm{Ti}^{47}$ & $3.3000 \mathrm{E}-06$ \\
\hline $\mathrm{Na}$ & $7.9000 \mathrm{E}-05$ & $\mathrm{Ti}^{48}$ & $2.9760 \mathrm{E}-06$ \\
\hline $\mathrm{Mg}^{24}$ & $3.9416 \mathrm{E}-03$ & $\mathrm{Ti}^{49}$ & $2.9488 \mathrm{E}-05$ \\
\hline $\mathrm{Mg}^{25}$ & $4.9900 \mathrm{E}-04$ & $\mathrm{Ti}^{50}$ & $2.1640 \mathrm{E}-06$ \\
\hline $\mathrm{Mg}^{26}$ & $5.4940 \mathrm{E}-04$ & $\mathrm{Mn}$ & $2.0720 \mathrm{E}-06$ \\
\hline $\mathrm{Al}$ & $3.7500 \mathrm{E}-04$ & $\mathrm{Fe}^{54}$ & $1.2000 \mathrm{E}-05$ \\
\hline $\mathrm{Si}^{28}$ & $1.7800 \mathrm{E}-03$ & $\mathrm{Fe}^{56}$ & $7.5401 \mathrm{E}-06$ \\
\hline $\mathrm{Si}^{29}$ & $9.0386 \mathrm{E}-05$ & $\mathrm{Fe}^{57}$ & $1.1836 \mathrm{E}-04$ \\
\hline $\mathrm{Si}^{30}$ & $5.9583 \mathrm{E}-05$ & $\mathrm{Fe}^{58}$ & $2.7335 \mathrm{E}-06$ \\
\hline$S^{32}$ & $9.4930 \mathrm{E}-05$ & $\mathrm{Zn}$ & $3.6378 \mathrm{E}-07$ \\
\hline $\mathrm{S}^{33}$ & $7.6000 \mathrm{E}-07$ & $\mathrm{Sr}^{84}$ & $8.9000 \mathrm{E}-06$ \\
\hline $\mathrm{S}^{34}$ & $4.2900 \mathrm{E}-06$ & $\mathrm{Sr}^{86}$ & $4.9840 \mathrm{E}-08$ \\
\hline $\mathrm{S}^{36}$ & $2.0000 \mathrm{E}-08$ & $\mathrm{Sr}^{87}$ & 8.7754E-07 \\
\hline $\mathrm{Cl}^{35}$ & $1.4398 \mathrm{E}-05$ & $\mathrm{Sr}^{88}$ & $6.2300 \mathrm{E}-07$ \\
\hline $\mathrm{Cl}^{37}$ & $4.6018 \mathrm{E}-06$ & $\mathrm{Ba}^{130}$ & $7.3496 \mathrm{E}-06$ \\
\hline $\mathrm{K}^{39}$ & $2.9003 \mathrm{E}-04$ & $\mathrm{Ba}^{132}$ & 4.1340E-09 \\
\hline $\mathrm{K}^{40}$ & $3.6387 \mathrm{E}-08$ & $\mathrm{Ba}^{134}$ & 3.9390E-09 \\
\hline $\mathrm{K}^{41}$ & $2.0931 \mathrm{E}-05$ & $\mathrm{Ba}^{135}$ & $9.4263 \mathrm{E}-08$ \\
\hline $\mathrm{Ca}^{40}$ & $7.0476 \mathrm{E}-03$ & $\mathrm{Ba}^{136}$ & $2.5709 \mathrm{E}-07$ \\
\hline $\mathrm{Ca}^{42}$ & $4.7037 \mathrm{E}-05$ & $\mathrm{Ba}^{137}$ & $3.0631 \mathrm{E}-07$ \\
\hline $\mathrm{Ca}^{43}$ & $9.8145 \mathrm{E}-06$ & $\mathrm{Ba}^{138}$ & $4.6433 \mathrm{E}-06$ \\
\hline
\end{tabular}

B.3.3 Aluminum - No composition data was supplied for the aluminum structural supports; Standard AL6061 was used in this model because of its use in related benchmark reports. The composition used was found in Perry's Chemical Handbook, and is described in Table B.7. 


\section{NEA/NSC/DOC/(95)03/II}

Volume II

HEU-MET-FAST-054

Table B.7. Aluminum Composition.

\begin{tabular}{||c|c|}
\hline Element & Atom Density \\
\hline \hline $\mathrm{Mg}^{24}$ & $5.3039 \mathrm{E}-04$ \\
\hline $\mathrm{Mg}^{25}$ & $6.7146 \mathrm{E}-05$ \\
\hline $\mathrm{Mg}^{26}$ & $7.3928 \mathrm{E}-05$ \\
\hline $\mathrm{Al}^{27}$ & $5.9143 \mathrm{E}-02$ \\
\hline $\mathrm{Si}^{28}$ & $3.2156 \mathrm{E}-04$ \\
\hline $\mathrm{Si}^{29}$ & $1.6258 \mathrm{E}-05$ \\
\hline $\mathrm{Si}^{30}$ & $1.0763 \mathrm{E}-05$ \\
\hline $\mathrm{Cr}^{50}$ & $2.6593 \mathrm{E}-06$ \\
\hline $\mathrm{Cr}^{52}$ & $5.1282 \mathrm{E}-05$ \\
\hline $\mathrm{Cr}^{53}$ & $5.8150 \mathrm{E}-06$ \\
\hline $\mathrm{Cr}^{54}$ & $1.4475 \mathrm{E}-06$ \\
\hline $\mathrm{Mn}^{55}$ & $4.4559 \mathrm{E}-05$ \\
\hline $\mathrm{Cu}^{63}$ & $4.8852 \mathrm{E}-05$ \\
\hline $\mathrm{Cu}^{65}$ & $2.1774 \mathrm{E}-05$ \\
\hline
\end{tabular}

B.2.4 Stainless Steel - There was no information provided regarding the type of stainless steel or the composition. However, standard SS304 was assumed based on its use in the related benchmark HEU-MET-FAST-026. The composition information was taken from Perry's' Chemical Handbook and is described in Table B.8.

Table B.8. Steel Composition.

\begin{tabular}{||c|c||}
\hline Element & Atom Density \\
\hline \hline $\mathrm{C}$ & $3.2209 \mathrm{E}-04$ \\
\hline $\mathrm{Si}^{28}$ & $1.5880 \mathrm{E}-03$ \\
\hline $\mathrm{Si}^{29}$ & $8.0635 \mathrm{E}-05$ \\
\hline $\mathrm{Si}^{30}$ & $5.3155 \mathrm{E}-05$ \\
\hline $\mathrm{Cr}^{50}$ & $7.6778 \mathrm{E}-04$ \\
\hline $\mathrm{Cr}^{52}$ & $1.4806 \mathrm{E}-02$ \\
\hline $\mathrm{Cr}^{53}$ & $1.6789 \mathrm{E}-03$ \\
\hline $\mathrm{Cr}^{54}$ & $4.1791 \mathrm{E}-04$ \\
\hline $\mathrm{Mr}^{55}$ & $1.7604 \mathrm{E}-03$ \\
\hline $\mathrm{Fe}^{54}$ & $3.4755 \mathrm{E}-03$ \\
\hline $\mathrm{Fe}^{56}$ & $5.4558 \mathrm{E}-02$ \\
\hline $\mathrm{Fe}^{57}$ & $1.2600 \mathrm{E}-03$ \\
\hline $\mathrm{Fe}^{58}$ & $1.6473 \mathrm{E}-04$ \\
\hline $\mathrm{Ni}^{58}$ & $5.1885 \mathrm{E}-03$ \\
\hline $\mathrm{Ni}^{60}$ & $1.9986 \mathrm{E}-03$ \\
\hline $\mathrm{Ni}^{61}$ & $8.6878 \mathrm{E}-05$ \\
\hline $\mathrm{Ni}^{62}$ & $2.7700 \mathrm{E}-04$ \\
\hline $\mathrm{Ni}^{64}$ & $7.0545 \mathrm{E}-05$ \\
\hline
\end{tabular}


B.2.5 Temperature Data - All experimental data were acquired at room temperature and all case model work was completed using room temperature data libraries.

B.2.6 Simplifications - Bias was assessed for the removal of aluminum and steel supports in the model. A simplified model would also approximate the concrete reflector outer edges as even, rather than including the small overhang of some of the concrete blocks. Detailed descriptions and calculations of the different sources of bias associated with simplifications are reported in Table B.1. The overall bias was not quantified, but was determined to be insignificant compared to the error associated with the hydrogen content in the concrete.

B.2.7 Experimental and Model $\mathbf{k}_{\text {eff }}$ - There is some uncertainty from the model itself. The detailed model $k_{\text {eff }}$ values vary greatly from the reported $k_{\text {eff }}$ values. This is believed to be related to the uncertainty in the concrete composition.

Table B.9 lists the reported $\mathrm{k}_{\text {eff }}$ values from the report as well as the $\mathrm{k}_{\text {eff }}$ values obtained by calculation with the detailed model. The reported values were the measured values decreased by 0.0014 to account for the aluminum worth; original ("measured") $k_{\text {eff }} v^{2}$ alues ${ }^{a}$ are also show in Table B.9.

Table B.9. $\mathrm{k}_{\mathrm{eff}}$ Data.

\begin{tabular}{|c|c|c|c|}
\hline Experiment \# & $\begin{array}{c}\text { Experimental } \\
\text { as Reported } \\
\text { asf } \\
\text { in Ref. 1 }^{\text {(a) }}\end{array}$ & Measured $\mathbf{k}_{\text {eff }}$ & $\begin{array}{c}{\text { Model } \mathbf{k}_{\text {eff }} \text { as }}_{\text {Calculated }} \\
\text { with MCNP }\end{array}$ \\
\hline \hline 1 & 1.0002 & 1.0016 & 1.01126 \\
\hline 2 & 0.9708 & 0.9722 & 0.97956 \\
\hline 3 & 1.0005 & 1.0019 & 1.00802 \\
\hline 4 & 0.9809 & 0.9823 & 0.98753 \\
\hline 5 & 1.0060 & 1.0074 & 1.01525 \\
\hline 6 & 0.9962 & 0.9976 & 1.00596 \\
\hline 7 & 1.0057 & 1.0071 & 1.01761 \\
\hline 8 & 1.0098 & 1.0112 & 1.01871 \\
\hline 9 & 1.0128 & 1.0142 & 1.02054 \\
\hline 10 & 1.0152 & 1.0166 & 1.0209 \\
\hline 11 & 1.0017 & 1.0031 & 1.00581 \\
\hline 12 & 0.9968 & 0.9982 & 1.00577 \\
\hline \hline
\end{tabular}

(a) Experimenter obtained these values by subtracting the measured reactivity of aluminum support structure (0.0014) from measured $\mathrm{k}_{\mathrm{eff}}$ values.

\footnotetext{
${ }^{a}$ Cross Section data from MCNP5 ENDF-B VII.0 data library. 
NEA/NSC/DOC/(95)03/II

Volume II

HEU-MET-FAST-054

\section{APPENDIX C: TYPICAL CASE-MODEL INPUT LISTINGS}

\section{C.1 MCNP Input}

The MCNP calculations with ENDF/B-VII.0 cross sections were run with 4150 generations of 40000 histories per generation and the first 150 generations skipped. All MCNP $k_{\text {eff }}$ calculations had an associated statistical calculation error of 0.00006 .

The following is the detailed MCNP input deck, including an interpretation of the concrete overhang, with comments for each case. The input deck can be used for all case models by appropriately placing or removing comment identifiers (the letter "c" at the beginning of the line) that correspond to the particular case desired. Please refer to Appendix B, Tables B.2 and B.3, and Table 5 in Section 1.2.5 to determine which case numbers correspond to what configuration.

In addition, the material cards for the various types of concrete used in the concrete composition sensitivity analysis are included for reference.

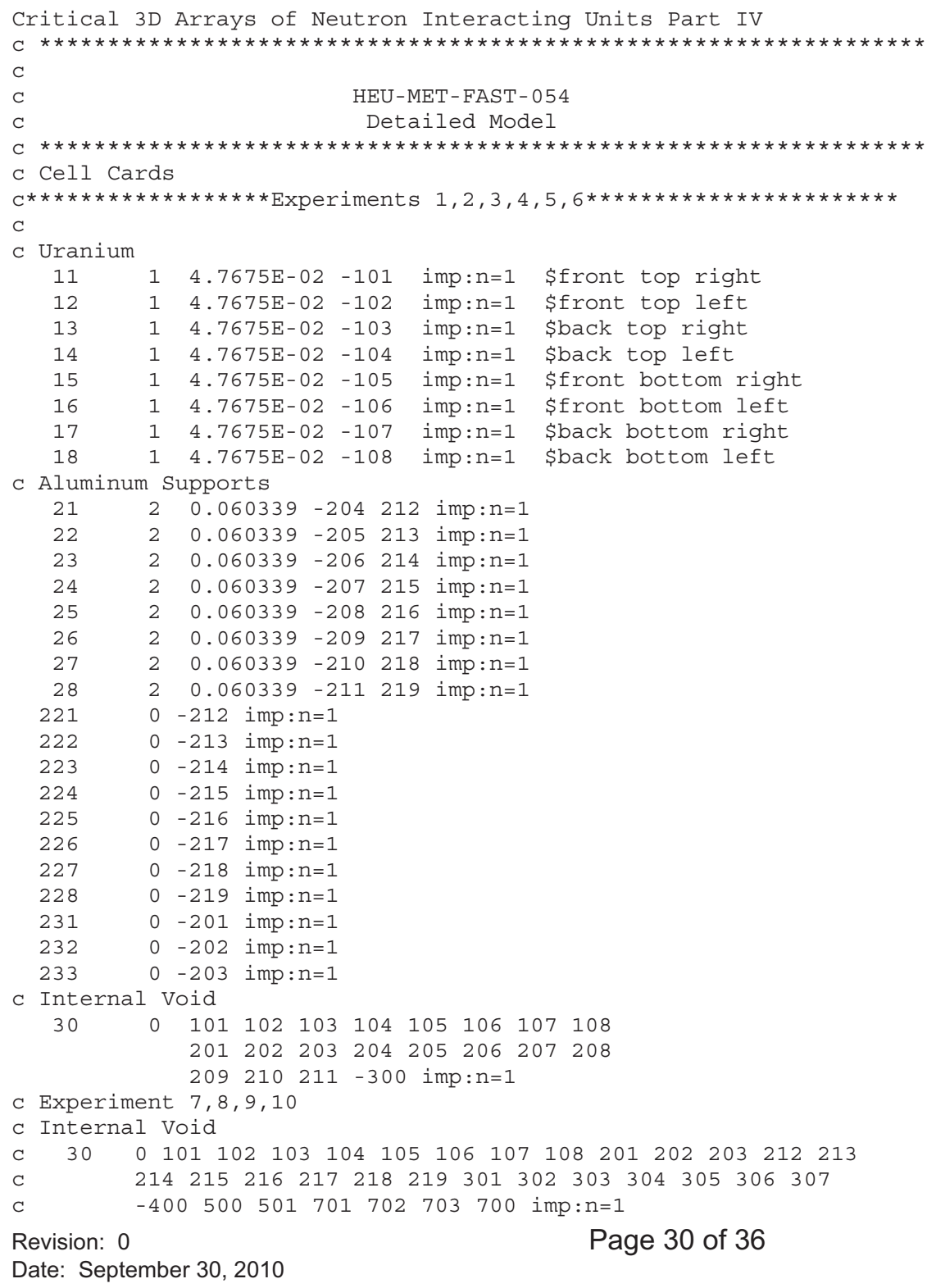




\section{NEA/NSC/DOC/(95)03/II \\ Volume II}

\section{HEU-MET-FAST-054}

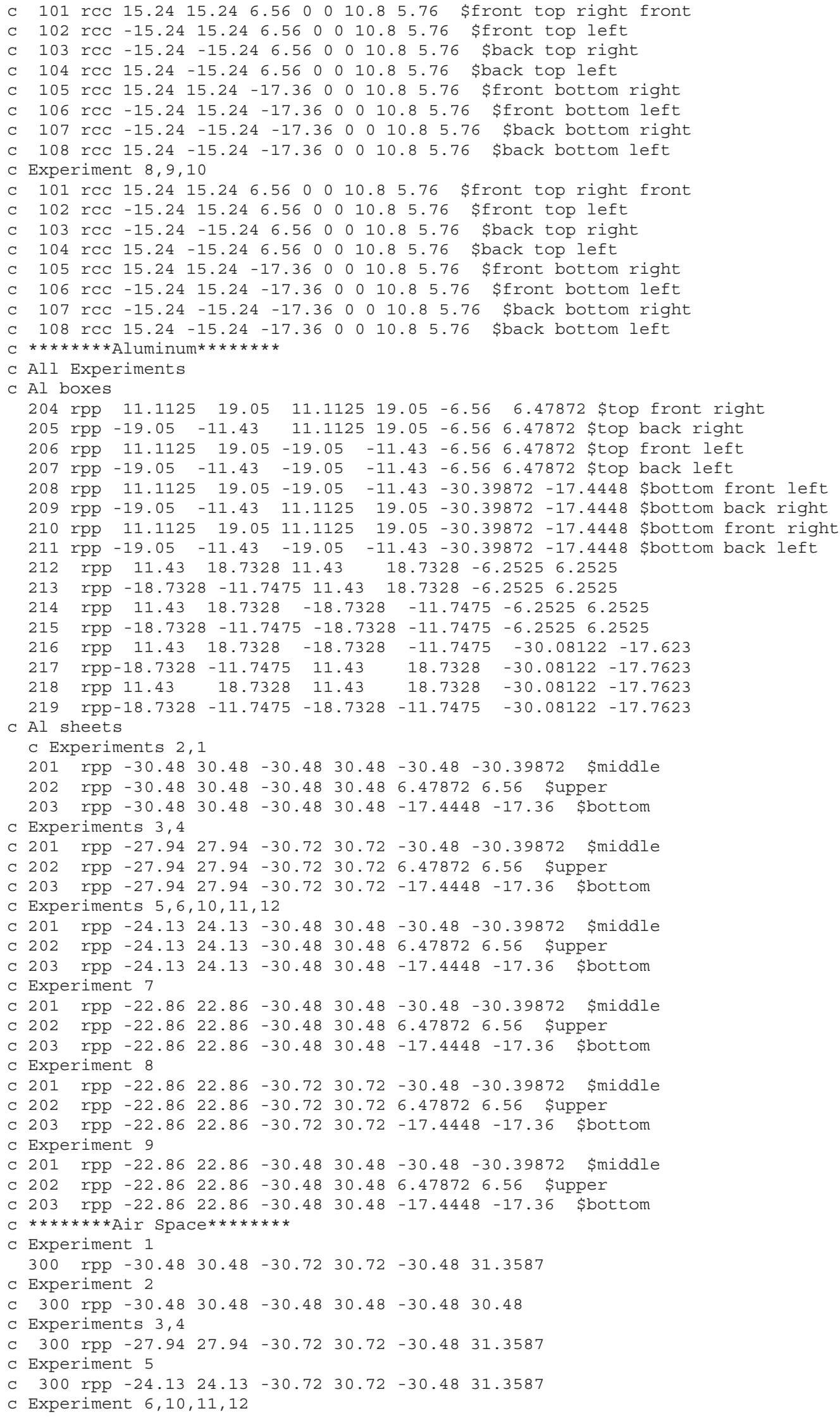


NEA/NSC/DOC/(95)03/II

Volume II

HEU-MET-FAST-054

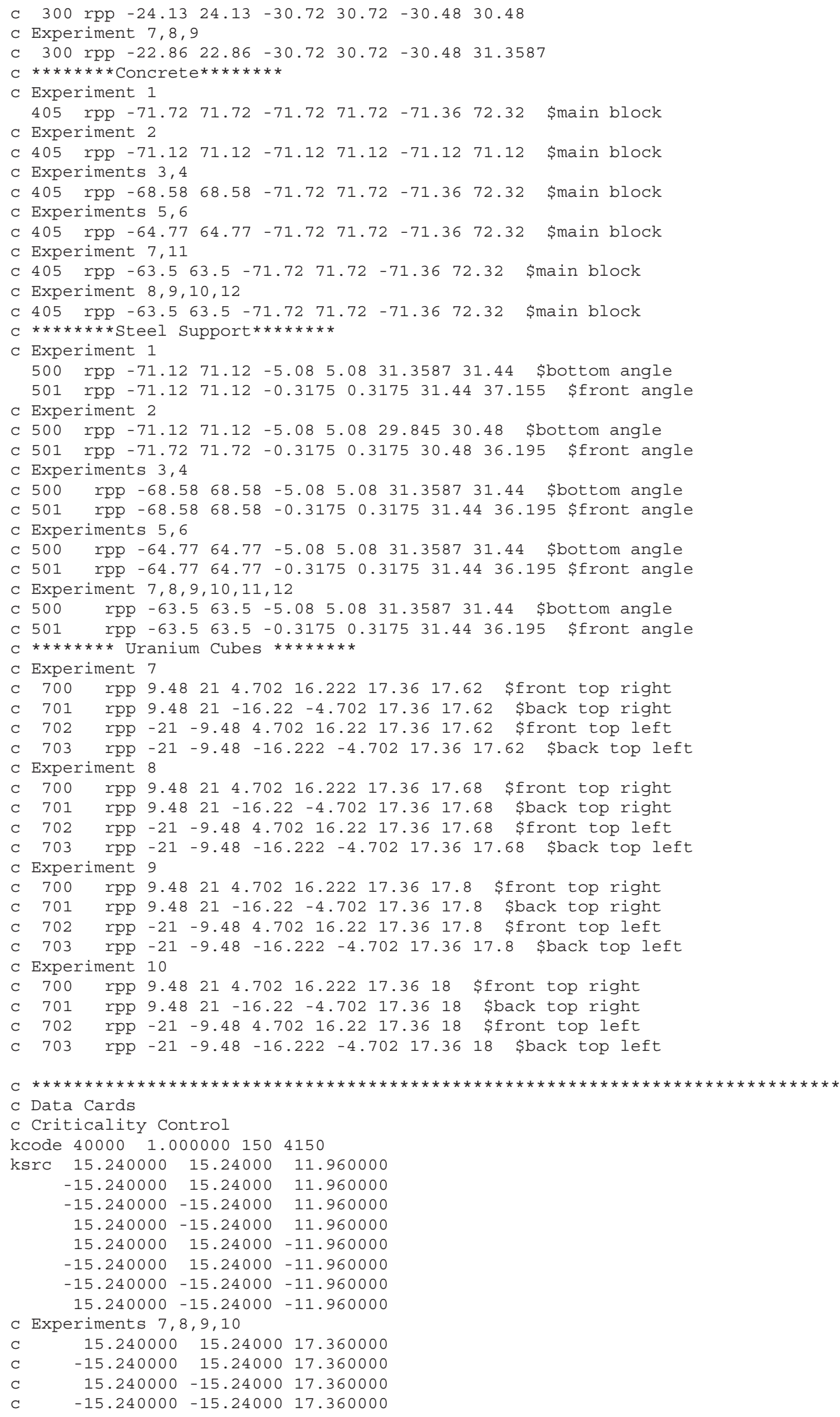




\section{NEA/NSC/DOC/(95)03/II \\ Volume II}

\section{HEU-MET-FAST-054}

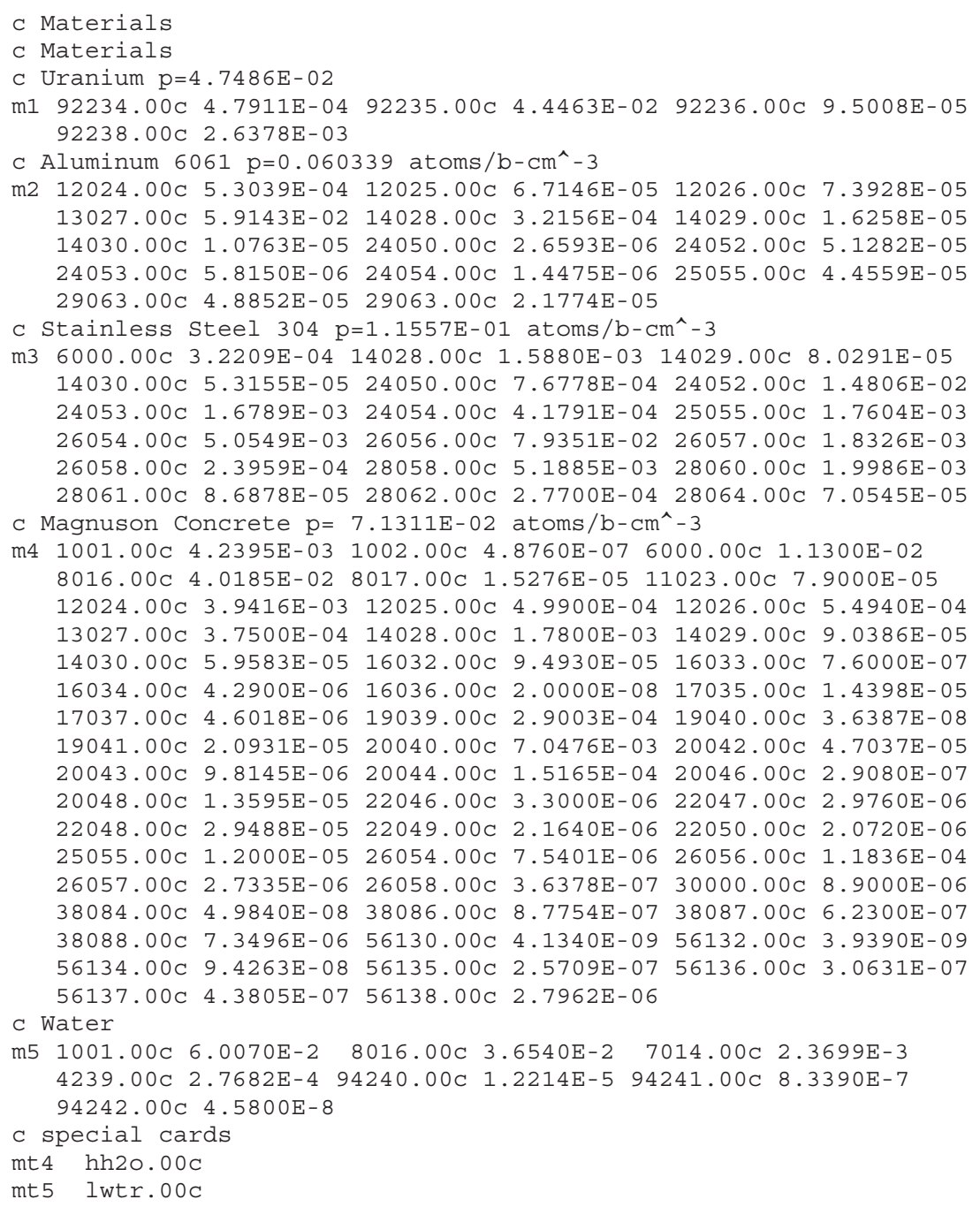


NEA/NSC/DOC/(95)03/II

Volume II

HEU-MET-FAST-054

\section{APPENDIX D: POSSIBLE ALTERNATIVE ORIENTATION OF AXES}

When creating the benchmark model, the evaluator noted that the experimenter recorded many more experiments in the logbook than were published in the experimental report. For this reason, it was felt that greater importance should be given to the general statements that were applied to the experiments as a whole, rather than the comments provided within each experiment. There was no sure way to correspond each experiment in the logbook with those in the report, and it would be an error to assume that notes for a particular permutation apply to the whole series. However, it is reasonable to assume consistency between the experiments, as they were all very similar. If the comments in the first few recorded experiments are interpreted as true for all experiments, it is possible to reasonably arrive at a different geometric description of the model. Reasons for choosing such a description are presented below. ${ }^{a}$

The $x$ and $y$ axes should be exchanged from the presented model. (Because the overhang has essentially no effect and is omitted and the split table is closed for all configurations, this only affects orientation of the steel angle iron.) If the $x$ direction is east-to-west, as shown in figures, consider again the picture on logbook pg 134 of the plan view of the reflector. Changing the inner $x$ dimension from 60.96 to 55.88 means that they would need to find some narrower blocks for the north and south walls in order to get the $55.88 x$ inner width. On the other hand, if the X axis was perpendicular to the plane between table halves and the $Y$ axis was parallel to it, the experimenters would never need to change the east-west width of the north and south walls, and they could keep the three 20.32-cm-wide blocks (with half-cm gaps between them) for all the experiments. Also they would not need to move one big side reflector on each table closer to the other. They would only have to push either the south or north wall a little closer to the split edge of the table when they changed to narrower cells in the $x$ direction, and they would not need to use different widths of concrete blocks.

For the concrete-reflected experiments, the $Y$ dimension of all cells does not change throughout all the experiments; it is $+-15.24 \mathrm{~cm}$ (12 inches), which is 24 inches across for 2 cells.

On logbook page 140 - when they were just beginning the experiments and were developing their procedure and straightening concrete blocks, etc., and were more careful about what they were writing down - is the following:

\section{Measured size vert}

North $12 \times 243 / 16 \times(243 / 16+3 / 32)$

South $12 \times 243 / 16 \times(243 / 16+3 / 32)$
Top blocks canted

"6
Measured size
$12 \times 243 / 16 \times 249 / 64$
$10 \times 243 / 16 \times 243 / 8$
Top Blocks Canted

Top Blocks level!

It can be inferred from this that the first-size cells were on the North table and the second-size cells were on the South table.

\footnotetext{
${ }^{\text {a }}$ Alternative description by Virginia Dean.

${ }^{\mathrm{b}}$ This turns out to be the South wall.

Revision: 0

Date: September 30, 2010 


\section{NEA/NSC/DOC/(95)03/II \\ Volume II}

\section{HEU-MET-FAST-054}

Now also consider the last 2 lines. In order for the inside void regions to fit together when the two halves of the table are brought together, the second dimension would need to be in the direction parallel to the edges of the split table. This dimension does not change throughout the experiments.

The Y Void dimension inside the Reflector is constant at $+-30.72 \mathrm{~cm}$ ( $\sim 24.2$ inches) for all the real experiments (1-14) in Ref. 1. However, the X Void dimension inside the Reflector changes from 24 inches to $12+10=22$ inches to $9+9=18$ inches for the 3 experiments evaluated in HMF54.The next logbook page (141), middle of the page says:

Restacked South table so that cells are $10 \times 12 \times 12$ nominal, North table $12 \times 12 \times 12$

$$
4 e a
$$

cells

This says, even more directly, that $10 \times 12 \times 12$ cells were on the South table and $12 \times 12 \times 12$ cells were on the North table. In order for the 2 void regions on the 2 table halves to fit together to make a cuboid void region for the core, the direction of the 10-inch dimension could not be parallel to the plane between split tables. 